\title{
Toxicological effects of the waste of the sugarcane industry, used as agricultural fertilizer, on the test system Allium cepa
}

\author{
Leonardo Ramos Anacleto a, Matheus Mantuanelli Roberto ${ }^{\text {a, b }}$, \\ Maria Aparecida Marin-Morales a, * \\ a Universidade Estadual Paulista (Unesp), Departamento de Biologia, Instituto de Biociências, Rio Claro, São Paulo, Brazil \\ b Centro Universitário Hermínio Ometto (UNIARARAS), Araras, São Paulo, Brazil
}

\section{H I G H L I G H T S}

- Sugarcane filter cake is largely used as a natural fertilizer in Brazil.

- There is no evidence of safe use of sugarcane filter cake in crops.

- The direct application of this solid waste could harm the local biota.

- Biodegradation of six months can reduce the toxic effects of sugarcane filter cake.

\section{A R T I C L E I N F O}

\section{Article history:}

Received 30 July 2016

Received in revised form

14 December 2016

Accepted 5 January 2017

Available online 6 January 2017

Handling Editor: Frederic Leusch

\section{Keywords:}

Bioremediation

Chromosomal aberrations

Micronuclei

Sugarcane filter cake

Sugarcane bagasse

\begin{abstract}
A B S T R A C T
Sugarcane is cultivated in tropical countries for sugar and ethanol production. In Brazil, this culture is among the most profitable with a production of 658.7 million tons/harvest. Sugarcane filter cake (SCFC) is a waste rich in organic matter and micronutrients, but also contains toxic metals. As it has been used as fertilizer and there is not enough knowledge about its environmental impacts, this work assessed the genotoxicogenetic effects of raw SCFC and associations with soil and sugarcane bagasse (SCB), by Allium cepa tests. Six associations of SCFC + soil and five associations of SCFC + soil + SCB were tested at three moments of degradation: initial (T0), 3 and 6 months (T1 and T2). Genotoxicogenetic assays were performed with solid substrates of these associations and with their respective aqueous extracts. Chemical analysis showed a decrease in metals, total organic carbon and nitrogen after 6 months of biodegradation, complying with Brazilian laws. In general, the combination of SCFC + soil + SCB was better than using only SCFC. T0 solubilized samples of different associations composed by highest quantities of SCFC inhibited the MI and induced CA without presenting mutagenicity (except for 75\%-SCFC + soil + SCB). T1 samples showed more cytotoxicity than T0 samples, and also presented genotoxic and mutagenic effects. Solid substrate and solubilized associations of SCFC + soil + SCB of T2 samples had no toxicity. These results suggest 6 months of biodegradation and the SCB adding as effective to reduce toxicogenetic effects induced by SCFC. Also, small proportions of SCFC interfered less on the A. cepa test-system when compared with those containing high quantities of residue.
\end{abstract}

๑) 2017 Elsevier Ltd. All rights reserved.

\section{Introduction}

Sugarcane is one of the main world crops because of ethanol and sugar production. Brazil is known worldwide for its agricultural potential and has sugarcane as one of its main crops, whose production of ethanol and sugar comprises approximately $2.0 \%$ of the

\footnotetext{
* Corresponding author.

E-mail address: mamm@rc.unesp.br (M.A. Marin-Morales).
}

gross domestic product (GDP) (Neves and Trombin, 2014). For the sugarcane harvest of $2015 / 16$, it is estimated that approximately 8995.5 thousand hectares are used which will correspond to a production that exceed 658.7 million tons of sugarcane to harvest (CONAB, 2015).

Vinasse, sugarcane bagasse (SCB) and sugarcane filter cake (SCFC) are wastes generated in the production of sugar and ethanol. These residues have high rates of organic matter and many nutrients, which allow it to be reused as agricultural fertilizers, as it could reestablish nutrients to the soil, improve aeration (in the case 
of SCB) and provide suitable conditions for growing crops (Partha and Sivasubramanian, 2006). The SCB is rich in lignocellulose and because of that has the capacity to increase water retention and enhance the porosity of contaminated soils. Due to biostimulant properties of SCB, this compound is often used to assist biodegradation of toxic compounds present in soil (Trejo-Hernández et al., 2007).

The SCFC, a residue generated in alcohol mills during the process of clarification of sugarcane juice, is one of the major byproducts used in the culture of sugarcane. According to Alvarenga and Queiroz (2009) and Prado et al. (2013), around 30-40 kg of SCFC are generated for each ton of sugarcane processed, being that based on the estimated productivity for the 2015/2016 harvest (CONAB, 2015), from 19.7 to 26.3 million tons of SCFC will be produced. This residue has been widely used in the sugarcane fields themselves due to its great amount of nutrients. However, in addition to nutritional qualities to the soil this product may contain metals such as $\mathrm{Zn}, \mathrm{Cu}, \mathrm{Cd}, \mathrm{Cr}$, Ni (Gupta et al., 2011) and other toxic compounds that can harm the crop and the environment, which effects are still poorly known.

Biodegradation is considered as a feasible option to remediate soils influenced by organic and inorganic compounds that have toxic potential, since this process is based on using microorganisms and/or plants capable to remove xenobiotics from impacted areas (Christofoletti et al., 2013). Thus, there are several ways to stimulate microorganisms already found in soil or environmental samples to act efficiently in the removal of toxic compounds. Leite et al. (2015) evaluated the characteristics of different sugarcane wastes assessed by anaerobic digestion to produce methane and showed that SCB has an important part in the process.

SCB contributes with the maintenance of nitrogen bioavailability while the SCFC has high levels of nitrogen and another essentials nutrients for plants, but many of these nutrients are lost before plant absorption. Thus, SCB enhances the maintenance of $\mathrm{C}: \mathrm{N}$ ratio in the crop by providing carbon and holding nitrogen in the soil, which is essential for microorganisms to biodegrade the present organic matter (Zhang and Sun, 2016). Merging SCFC and SCB in the environment of anaerobic degradation could give the maintenance of $\mathrm{C}: \mathrm{N}$ ratio, preventing possible nutrient losses from this mixture and enhancing its potential as crop fertilizer.

Tests performed with higher plants are effective in the evaluation of the cytotoxicity, genotoxicity and mutagenicity of various chemicals (Rank et al., 2002). Among these plants, the Allium cepa species has been considered an efficient test organism for studies of basic biological mechanisms of action of environmental contaminants (Grant, 1994; Bushra Ateeq et al., 2002; Fernandes et al., 2007; 2009), as well as for the validation of the effectiveness of biodegradation (Mazzeo et al., 2011; Souza et al., 2013a,b; Mazzeo et al., 2015), being routinely used for the evaluation of environmental pollution (Bianchi et al., 2011; Herrero et al., 2012; Bianchi et al., 2016).

This organism has as main characteristics their kinetics of proliferation, rapid growth of their roots, large number of cell division, its high tolerance to different conditions of cultivation, their availability during the whole year, its easy handling, chromosomes in reduced number $(2 n=16)$ and large size (Rank and Nielsen, 1998; Matsumoto et al., 2006; Leme and Marin-Morales, 2009), in addition to being easily stained and observed under light microscopy (Kurás et al., 2006). Thus, this species has the essential characteristics for a bioindicator and it is considered an important test organism for environmental assessments by responding effectively to the action of many known genotoxic/mutagenic agents (Evseeva et al., 2003).

The determination of the frequency of chromosomal aberrations (CA) and of micronuclei (MN), during mitosis in meristematic cells of $A$. cepa, consists in an easy method to determine the mechanisms of action of several genotoxic and mutagenic compounds (Leme and Marin-Morales, 2009; Mazzeo et al., 2011; Souza et al., 2013b).

Due to the evidence of toxic compounds in SCFC and little information about the toxicological effects of this agroindustrial residue, there is a need to understand their physicochemical properties and to determine the level of influence that this sugarcane by-product can have in biological systems. Therefore, the objective of this work was to detail the chemical composition of SCFC and assess its cytotoxic, genotoxic and mutagenic potential on the test organism A. cepa, before, during and after the process of biodegradation.

\section{Materials and methods}

\subsection{Biological material}

In this study, seeds of $A$. cepa were used, acquired from Isla ${ }^{\circledR}$ (Isla Sementes Ltda., Brazil), from the same batch and variety. These seeds are free of agrochemicals.

\subsection{Sugarcane residues}

SCFC and SCB were kindly provided by a sugar-ethanol plant of the city of General Salgado, located in the interior of the state of São Paulo, Brazil.

\subsection{Chemical analyses and samples preparation}

This study evaluated the toxic potential of residues of sugarethanol mills (SCFC and SCB). In this analysis, 13 different associations of the SCB and SCFC were used with a soil, as shown in Table 1.

Samples of SCFC were chemically analyzed by an outsourced specialized laboratory (Analytical Technologies, São Paulo, Brazil). It was performed the metal analyses ( $\mathrm{Cd}, \mathrm{Cr}, \mathrm{Co}, \mathrm{Cu}, \mathrm{Fe}, \mathrm{Pb}, \mathrm{Mg}, \mathrm{Ni}, \mathrm{P}, \mathrm{K}$, Na e Zn) based on the method 6010C (SW-846) (EPA, 2007), by an inductively coupled plasma-atomic emission spectrometry (ICPAES). Also, the analyses to quantify the total nitrogen were executed by the $4500-\mathrm{NH}_{3}$ methods proposed by Standard Methods for the Examination of Water and Wastewater (APHA, 2012), by the ammonia-selective electrode method. Furthermore, the total organic carbon (TOC) was measured based on the method recommended by Embrapa (Brazilian Agricultural Research Corporation) (Donagema et al., 2011), which consists in the wet oxidation-redox titration method (modified Walkley-Black method).

The soil used in the preparation of samples and in the treatment control was collected on the grounds of the Experimental Area from

Table 1

Proportion of SCFC, SCB and soil used in the preparation of the different associations.

\begin{tabular}{|c|c|c|c|c|}
\hline Samples (percentage of SCFC) & $\mathrm{SCFC}(\mathrm{Kg})$ & Soil (Kg) & $\mathrm{SCB}(\mathrm{Kg})$ & Total weight $(\mathrm{Kg})$ \\
\hline $0 \%(\mathrm{SC})$ & 0 & 8 & 0 & 8 \\
\hline $5 \%$ & 0.4 & 7.6 & 0 & 8 \\
\hline $10 \%$ & 0.8 & 7.2 & 0 & 8 \\
\hline $25 \%$ & 2 & 6 & 0 & 8 \\
\hline $50 \%$ & 4 & 4 & 0 & 8 \\
\hline $75 \%$ & 6 & 2 & 0 & 8 \\
\hline $100 \%$ & 8 & 0 & 0 & 8 \\
\hline $0 \%(\mathrm{SCBC})$ & 0 & 7.6 & 0.4 & 8 \\
\hline $5 \%$ & 0.4 & 7.2 & 0.4 & 8 \\
\hline $10 \%$ & 0.8 & 6.8 & 0.4 & 8 \\
\hline $25 \%$ & 2 & 5.6 & 0.4 & 8 \\
\hline $50 \%$ & 4 & 3.6 & 0.4 & 8 \\
\hline $75 \%$ & 6 & 1.6 & 0.4 & 8 \\
\hline
\end{tabular}

SCFC: sugarcane filter cake; SCB: sugarcane bagasse; SC: soil control; SCBC: sugarcane bagasse control. 
the Biosciences Institute, UNESP - Univ. Estadual Paulista - Rio Claro/SP, Brazil, by being regarded as non-polluted (Montagnolli et al., 2009). This soil was sieved in mesh of $2.0 \mathrm{~mm}$ and, subsequently, its initial moisture was calculated in accordance with the procedure determined by ABNT NBR 15537 (2014), where: $10 \mathrm{~g}$ of natural soil was weighed (wet mass) and after drying at $105{ }^{\circ} \mathrm{C}$ during $24 \mathrm{~h}$, a new weighing was performed (dry mass). The results obtained were used in the following formula for the determination of the initial moisture (M): $M(\%)=[($ wet mass - dry mass $) \div$ dry mass $] \times 100$. This same technique was used to determine the initial moisture of SCFC.

Thus, after obtained the values of initial moisture for the SCFC (27\%) and for the soil (18\%), the associations of soil + SCFC + SCB had their final moisture adjusted to a range of $40-60 \%$, in accordance with the ABNT NBR 15537 (2014) standard.

The $\mathrm{pH}$ of the samples was measured according to the method 9040C (SW-846) (EPA, 2004), while the $\mathrm{pH}$ of the associations was measured in a mixture of substrate and distilled water (in the proportion of $1: 5$, respectively), previously homogenized by agitation for $12 \mathrm{~h}$, followed by a rest period of more $12 \mathrm{~h}$, according to the same protocol (ABNT NBR 15537, 2014).

After the measurement and adjustment of the initial moisture and the $\mathrm{pH}$, the associations were placed in stainless-steel containers, arranged in a greenhouse, at room temperature $\left(\right.$ ca. $26^{\circ} \mathrm{C}$ ). For the biodegradation, the initial moisture of the samples was adjusted to $60 \%(\mathrm{~m} / \mathrm{m})$ and each mixture was collected and analyzed in three different periods (initial - T0; after 3 months - T1; and after 6 months - T2). None microorganism was added to these mixtures, allowing only the microbiota existent on the soil, SCB and SCFC execute the degradation, being this process based on natural attenuation. During this process, the moisture levels of the mixtures were maintained by adding $500 \mathrm{~mL}$ of water once a week. As the samples were not mixed or aerated during this period, we could consider that an anaerobic biodegradation was performed. Each association had two replicas.

Furthermore, for each treatment time (T0, T1 and T2), solubilized samples (aqueous extracts) were prepared from the associations in accordance with other protocol (ABNT NBR 10006, 2004). For the preparation of these samples, $250 \mathrm{~g}$ (dry mass) of each association prepared were used, being mixed with $1 \mathrm{~L}$ of ultrapure water in a beaker with a capacity of $2 \mathrm{~L}$. These mixtures were maintained in an incubator with temperature of $24.0 \pm 2.0^{\circ} \mathrm{C}$, for 7 days. After this period, the homogenates were filtered with a membrane of $0.45 \mu \mathrm{m}$ of porosity to be used in the exposure of the A. cepa seeds.

\subsection{Test of Allium cepa}

The exposure of $A$. cepa seeds followed the protocol determined by Mazzeo et al. (2015).

The exposure was performed by using Petri dishes lined with filter paper, with the adding of solid samples of the associations or with the different solubilized samples, individually. This exposure was repeated for each 3 different times of biodegradation (T0, T1 and T2). These Petri dishes received the $A$. cepa seeds and were maintained in an incubator at $22.0 \pm 2.0^{\circ} \mathrm{C}$. Concomitantly to the treatments, a negative control (NC) with ultrapure water and two positive controls (PC) with two known genotoxic agents were performed: 1) clastogenic agent: methyl methanesulfonate (MMS Sigma-Aldrich - CAS: 66-27-3), in a concentration of $10 \mathrm{mg} / \mathrm{L} ; 2$ ) aneugenic agent: the commercial herbicide trifluralin in the concentration of $0.84 \mathrm{~g} / \mathrm{L}$. A soil control (SC) and a sugarcane bagasse control (SCBC) were also performed to ensure the absence of substances with genotoxic potential in these samples, which were also used in the associations with the SCFC.
For the experiments with the solid substrates, when the roots reached approximately $1.5 \mathrm{~cm}$ of length (ca. $120 \mathrm{~h}$ of exposure), half of the seeds were collected and fixed in Carnoy I (3:1 - ethanol/ acetic acid $-v / v)$, while the rest was transferred to other Petri dishes containing new filter paper soaked with only ultrapure water, for a recovery period of $48 \mathrm{~h}$. For the test with the solubilized samples, the procedure was the same, however without the recovery period.

The slides were prepared according to the work of Bianchi et al. (2011), in which the fixed roots were submitted to acid hydrolysis with $\mathrm{HCl}(1 \mathrm{M})$, for $10 \mathrm{~min}$ at $60^{\circ} \mathrm{C}$, followed by Feulgen's reaction (Schiff's reactive), for $2 \mathrm{~h}$. Thereafter, the meristematic regions of roots of $A$. cepa were sectioned on slides, counterstained with a drop of acetic carmine (2\%), covered with coverslip and carefully crushed. The coverslips were removed in liquid nitrogen and, after dried, the slides were mounted in synthetic resin (Entellan ${ }^{\circledR}$, Merck Millipore, Darmstadt, Germany), for subsequent microscopic evaluation.

The analysis criteria were determined from the work of Leme and Marin-Morales (2009). The mitotic index (MI), related to the number of cells in division ( $\mathrm{MI}=$ number of cells in division present in 5000 cells counted per sample), as well as the number of cells in the process of cell death (vacuolization of cytoplasm and/or nuclei, heteropyknotic nuclei, among others), served as a criterion for the assessment of cytotoxicity. The analysis of CA was based on the different types of chromosomal abnormalities (losses, breaks, bridges and delays, among others), observed in the different phases of cell division (prophase, metaphase, anaphase, telophase), being gathered into a single group considered as the genotoxicity endpoint division ( $\mathrm{CA}=$ number of cells carrying chromosomal abnormalities in 5000 cells counted per sample). The mean of micronucleated cells (presenting micronucleus - MN) was also analyzed and characterized as a criterion for the assessment of the mutagenicity, establishing a third parameter for evaluation division ( $\mathrm{MN}=$ number of cells carrying micronucleus in 5000 cells counted per sample). Examples of changes can be observed in Fig. 1. The analysis was made by counting of 500 cells, being 10 slides per sample, totaling 5000 cells counted for each different time of biodegradation.

The statistical analysis was first performed by D'Agostino \& Pearson method $(p<0.05)$, to determine the pattern of distribution of the results obtained. The results that presented normal distribution were evaluated by the parametric test One-Way ANOVA/ Dunnet $(p<0.05)$ and the others, those who did not present a normal distribution, were submitted to non-parametric KruskalWallis/Dunn $(p<0.05)$. All statistical analysis was performed using the software GraphPad Prism 6.0 (San Diego, California, USA).

\section{Results and discussion}

The SCFC sample was chemically analyzed by the company Analytical Technologies (São Paulo, Brazil), using the method 6010C (SW-846) (EPA, 2007). The results obtained in the chemical analysis are presented in Table 2.

The $\mathrm{pH}$ of the samples was measured and the values of 5.55 (initial sample) and 4.74 (final sample -6 months of biodegradation) were obtained. As the soil $\mathrm{pH}$ influences in the availability of nutrients for the plants, it is important to maintain the $\mathrm{pH}$ value within the range ideal for the corresponding soil. In accordance with Schimitz et al. (2002), the ideal pH varies according to the type of soil: mineral based soil must have a pH between 6.0 and 7.0 and organic matter based soil must have a pH between 5.2 and 5.5 . Thus, the introduction of SCFC decreased the $\mathrm{pH}$ of the soil to levels considered between normal and low, suggesting a possible acidification for farmable soil, which may even require a pH correction 

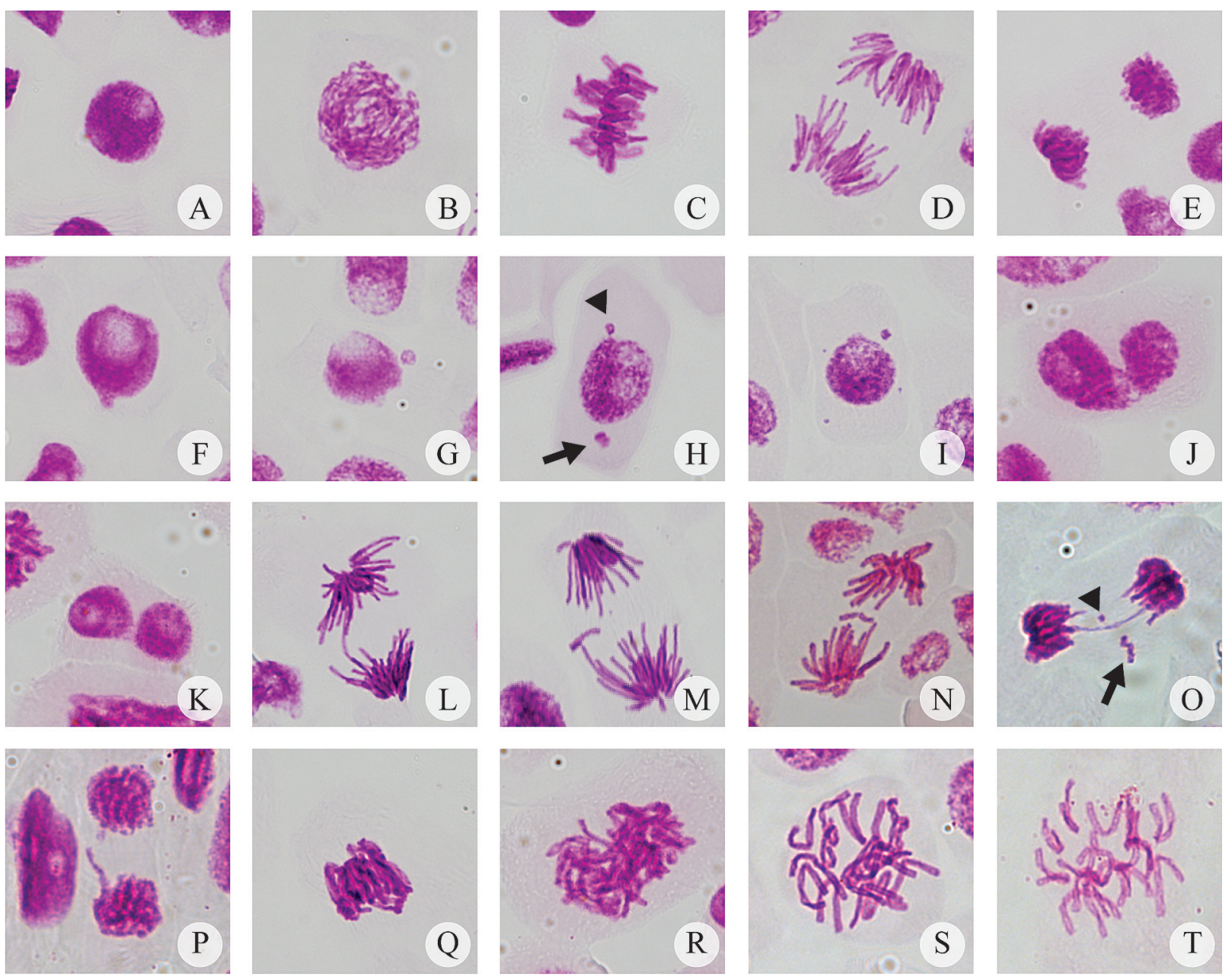

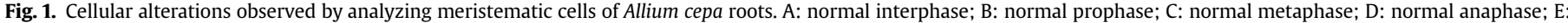

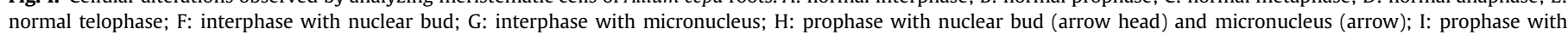

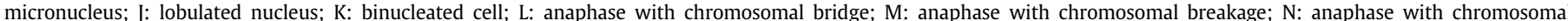

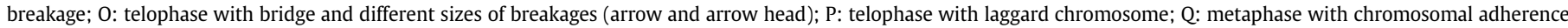
(stickiness); R: polyploid metaphase; S-T: C-metaphase.

\section{Table 2}

Physicochemical parameters evaluated for the initial sample (T0) and final sample after 6 months of biodegradation (T2), compared with the guiding values from the CETESB's Board Decision 195-2005-E (CETESB, 2005) and from the CONAMA Resolution 420/2009 (MMA, 2009).

\begin{tabular}{|c|c|c|c|c|c|}
\hline \multirow[t]{2}{*}{ Parameters } & \multicolumn{2}{|c|}{ Sugarcane Filter Cake samples $(\mathrm{mg} / \mathrm{kg}$ ) } & \multicolumn{3}{|c|}{$\begin{array}{l}\text { Guiding values } \\
\text { (CETESB - mg/kg) }\end{array}$} \\
\hline & Initial sample (T0) & Final sample (T2) & V.Q.R. & P.V. & I.V. \\
\hline $\mathrm{Cd}$ & $<2.55$ & $<1.29$ & $<0.5$ & 1.3 & 3,6 \\
\hline Co & $<3.83$ & $<1.93$ & 13 & 25 & 35 \\
\hline $\mathrm{Cr}$ & 30.6 & 18.3 & 40 & 75 & 150 \\
\hline $\mathrm{Ni}$ & $<5.10$ & $<2.58$ & 13 & 30 & 70 \\
\hline $\mathrm{Pb}$ & $<5.10$ & $<2.58$ & 17 & 72 & 180 \\
\hline $\mathrm{Zn}$ & 177.2 & 43.1 & 60 & 300 & 450 \\
\hline $\mathrm{Cu}$ & 51.3 & 22.2 & 35 & 60 & 750 \\
\hline $\mathrm{Fe}$ & 8910.7 & $11,743.6$ & - & - & - \\
\hline K & 4517.9 & 1239.4 & - & - & - \\
\hline $\mathrm{P}$ & 2107.4 & 686.0 & - & - & - \\
\hline $\mathrm{Mg}$ & 1369.9 & 362.8 & - & - & - \\
\hline $\mathrm{Na}$ & 62 & 47.8 & - & - & - \\
\hline TOC & $88.6^{a}$ & $3.62^{\mathrm{a}}$ & - & - & - \\
\hline $\mathrm{N}$ & 6122.4 & 330.35 & - & - & - \\
\hline
\end{tabular}

TOC: total organic carbon; V.Q.R.: value for quality reference; P.V.: prevention value; I.V.: intervention value.

${ }^{a}$ expressed in percentage. by the process of liming.

After 6 months of biodegradation, there was a decrease in the concentration of chemical compounds analyzed, except for Fe, which showed an augmentation. Some of heavy metals like $\mathrm{Cu}$ and $\mathrm{Zn}$ are micronutrients required by several physiological processes, but they can be toxic in high concentrations. However, there are metals like $\mathrm{Cd}$ and $\mathrm{Pb}$ without a known function in plants, being toxic even in low concentrations (Vitorino et al., 2012). It is known that the control of heavy metals speciation in soils is based on processes like precipitation, adsorption and complexation, which could decrease some metals amount while increasing others, also interfering in their availability in environmental samples. Complexation reactions are the most important because they can change solubility, charge and redox potential of metals (Bezerra et al., 2009). These metals can form complexes with inorganic ligands such as $\mathrm{Cl}^{-}$and $\mathrm{SO}_{4}^{2-}$ and also with dissolved organic matter present in soils, in which metals like $\mathrm{Pb}, \mathrm{Cd}, \mathrm{Zn}$ and $\mathrm{Ni}$ can strongly bind. Due to this complex formation, metals can have its mobilization and transport altered and they can be unavailable to living beings (Weng et al., 2002). The quantities of metals present in the soil were compared with the limits established by the CONAMA Resolution 420/2009 (MMA, 2009), based on the decision of the Executive Decision 195-2005-E of CETESB (CETESB, 2005), which 
establishes the quality reference values (Q.R.V.), prevention values (P.V.) and intervention values (I.V.). These are the guiding values, derived from numerical criteria, obtained through data present in international scientific literature (CETESB, 2005) to regulate the introduction of substances in the soil and to monitor the quality of this soil when some compound exceeds. Thus, it is observed that no value obtained on the chemical analysis after biodegradation surpasses the P.V. pre-established by the Executive Decision of 1952005-E of CETESB (CETESB, 2005) and by CONAMA Resolution 420/ 2009 (MMA, 2009).

From the data obtained in chemical analysis it is believed that the SCFC could be used in agriculture, since the values of micronutrients are constantly monitored, together with the chemical constitution of soil itself, in order to avoid toxic effects to plants and other organisms potentially exposed.

After the completion of the bioassays with the A. cepa test system, the potential of cytotoxicity (MI and mean of cell death), genotoxicity (mean of chromosomal aberrations) and mutagenicity (mean of micronuclei) were evaluated.

The results obtained after the exposure of seeds to different associations of solid substrates and to their respective solubilized samples, as well as the results obtained after the recovery test, before the biodegradation (T0), are presented in Table 3 .

It is observed that, in relation to cytotoxicity, the soil control (SC) and the sugarcane bagasse control (SCBC) interfered in MI of meristematic cells, by significantly $(p<0.05)$ inhibiting the number of cells in division. This effect was verified for the exposures made with the samples in the form of solid substrates (SC and SCBC) and solubilized (SCBC only), even after the period of recovery (only for the SC). Despite the inhibition caused, none of these controls (SC and SCBC) was able to induce cell death in statistically significant quantities $(p<0.05)$. It was verified a significant difference in relation to cellular death only for the solubilized sample of the association with 75\%-SCFC. Probably, for this association the process of solubilization induced a greater extraction of hydrophilic cytotoxic compounds present in SCFC (Table 3).

There was an inhibition of the MI for the association of solid substrates of 5\%-SCFC and 75\%-SCFC, however this inhibition was not observed for $100 \%$-SCFC sample and for the solid substrates of the associations involving the SCB (Table 3). The solubilized samples of $100 \%-$ SCFC, $50 \%-$ SCFC + SCB and 75\%SCFC + SCB induced a decrease in MI, even after the recovery test. Probably, these associations still contained hydrosoluble contaminants with cytotoxic activity or inhibitors of cell division. Similar results were obtained by Bhat et al. (2014), in which study the root growth and the MI of A. cepa was inhibited after exposure to pressmud sludge extract (pre and post-vermicompost with Eisenia fetida) for 3 and $6 \mathrm{~h}$. Bhat et al. (2016) also found a decreased MI in A. cepa cells induced by $\mathrm{SCB}$, but the authors did not suggest a reason for this result because of most of cytotoxic effects were neutralized after vermicomposting. One of the possible causes of the decline of the MI may be related to the presence of $\mathrm{Cu}, \mathrm{Zn}$ and $\mathrm{Fe}$ in the sample, as observed in the chemical analysis. These same authors related this inhibition to the presence of transition metals, but they found an increase of metals after vermicomposting (Bhat et al., 2014). According to the observations of Yildiz et al. (2009), the presence of copper sulfate inhibits the process of cell division of meristems of $A$. cepa. In this study, the authors has tested two concentrations of copper sulfate $(1.5$ and $3.0 \mathrm{mg} / \mathrm{L})$ and noted an inversely proportional relationship between the concentration of this compound and the MI (Table 3 ).

The delay in the growth of roots, as well as the inhibition of root growth and the appearance of withered roots represent a response of plant to the action of cytotoxic agents. Wierzbicka (1994) exposed roots of $A$. cepa to various concentrations of $\mathrm{Pb}$ by 6,12 and $24 \mathrm{~h}$, followed by another $48 \mathrm{~h}$ of recovery. In the first $12 \mathrm{~h}$ of exposure to several salts of lead, the authors observed the inhibition of cell division of meristematic cells, which culminated, after $18 \mathrm{~h}$ of treatment, in the presence of rootlet sprouts with tumors. These effects were reverted after a period of recovery of $18 \mathrm{~h}$.

Dovgaliuk et al. (2001) compared the effects of six salts, formed by different metal ions $\mathrm{Cd}, \mathrm{Pb}, \mathrm{Ni}, \mathrm{Al}, \mathrm{Cu}$ and $\mathrm{Zn}$, based on the analyzes of meristematic cells of onions. Among the compounds investigated, Ni showed a strong antimitotic activity, besides having promoted an increase in the percentage of chromosomal delays, multipolar anaphases and C-metaphases, when compared with the control test. These same effects were also observed by other authors (Fiskesjö, 1988; Steinkellner et al., 1998; Yi et al., 2007; Migid et al., 2007), which demonstrated a metal dose-dependent response for the decrease of $\mathrm{MI}$ and the induction of $\mathrm{MN}$, showing that the A. cepa test is sensitive to detect cytotoxicity and genotoxicity of metallic compounds.

Regarding the quantity of chromosomal aberrations (CA) observed in the results, both the SC and SCBC did not induce significant levels $(p<0.05)$ of damage in the meristematic cells of A. cepa, thus not presenting genotoxic potential (Table 3 ). The soil used in the experiments was collected in the same site of collection described by Montagnolli et al. (2009) as non-polluted, i.e. free of contaminants. However, despite the absence of genotoxicity and mutagenicity, our results have shown a cytotoxic potential by its ability to change the MI of meristematic cells of the test organism.

None of the associations tested in $\mathrm{T} 0$, both for the solid substrates as well as for the solubilized samples, induced statistically significant levels of chromosomal aberrations $(p<0.05)$. However, after the recovery time the associations with highest concentrations of SCFC (100\%-SCFC, 50\%-SCFC + SCB and 75\%-SCFC + SCB) induced significant amounts of $\mathrm{CA}$, when compared to the NC $(p<0.05)$. These results indicate that the samples of solid substrate have compounds or substances with genotoxic potential, whose effect only appears after an extended exposure, probably due to an accumulation of the agent inside the cells. However, these compounds are not released by the process of solubilization of the sample, but have the ability to persist in the cell, acting later on them. These results are different from those obtained by Bhat et al. (2014, 2016), which have found genotoxic effects for SCFC and SCB, prior to vermicompost practice. Based on our results and according to Siedlecka (1995), plants have a great potential to absorb metals, both essential for its metabolism (ex.: $\mathrm{Fe}, \mathrm{Cu}, \mathrm{Mn}, \mathrm{Mo}$ ) as nonessential (Ex.: $\mathrm{Cd}, \mathrm{Hg}$ and $\mathrm{Pb}$ ). The author describes that the nonessential metals may induce toxic effects even in low concentrations, but makes an exception that even essential metal may also induce such effects when in concentrations higher than necessary. Still according to the work of Siedlecka (1995), metals such as Zn and $\mathrm{Cu}$ are easily captured by the roots of plants and can accumulate in this structure.

In relation to the mutagenic potential, the absence of agents that induce micronuclei in the soil and bagasse controls was observed (SC and SCBC, respectively). Of all exposures performed, only the association of solid substrate with 75\%-SCFC and solubilized association of $75 \%$-SCFC + SCB had statistically significant results in relation to the $\mathrm{NC}$.

SCB has adsorbent characteristic (Souza et al., 2009), which can capture metals such as Pb and Ni (Santos et al., 2008). Costa et al. (2010) used the SCB powder to adsorb metals of industrial effluent and it has proven the great adsorbent potential of SCB on metals, even solubilized or as metal ions.

Among the associations tested in this study, it was observed that those which had the lowest concentrations of SCFC, in the presence or not of SCB, did not induce adverse effects to the A. cepa test organism (Table 3). In this way, these concentrations of SCFC appear to be viable to be used as source of nutrients, even without going 
Table 3

Mean of cellular alterations observed in meristematic cells of $A$. cepa exposed to different treatments, before the degradation period (initial sample - T0).

\begin{tabular}{|c|c|c|c|c|c|c|c|c|c|c|}
\hline & \multirow[t]{2}{*}{ Assay } & \multicolumn{3}{|l|}{ Controls } & \multicolumn{6}{|l|}{ SCFC } \\
\hline & & NC & PC-TRIF & PC-MMS & $5 \%$ & $10 \%$ & $25 \%$ & $50 \%$ & $75 \%$ & $100 \%$ \\
\hline \multirow[t]{3}{*}{ Gen. } & $\mathrm{S}$ & $0.96 \pm 0.79$ & $13.20 \pm 5.22^{*}$ & $6.89 \pm 3.70^{*}$ & $1.55 \pm 1.26$ & $2.07 \pm 1.33$ & $2.88 \pm 1.61$ & $2.02 \pm 1.11$ & $2.19 \pm 1.57$ & $3.30 \pm 2.42$ \\
\hline & SS & & & & $2.39 \pm 1.49$ & $2.70 \pm 1.73$ & $3.63 \pm 2.59$ & $2.09 \pm 1.21$ & $3.30 \pm 1.70$ & $1.70 \pm 0.88$ \\
\hline & $\mathrm{R}$ & $0.92 \pm 0.76$ & $9.45 \pm 3.98^{*}$ & $5.22 \pm 5.19^{*}$ & $2.08 \pm 1.69$ & $2.56 \pm 1.41$ & $1.67 \pm 0.86$ & $2.09 \pm 1.18$ & $2.56 \pm 2.08$ & $4.05 \pm 1.91^{*}$ \\
\hline \multirow[t]{3}{*}{ Mut. } & S & $0.09 \pm 0.27$ & $5.78 \pm 1.71^{*}$ & $15.36 \pm 5.56^{*}$ & $0.47 \pm 1.23$ & $0.63 \pm 0.73$ & $0.56 \pm 0.49$ & $1.28 \pm 0.64$ & $0.93 \pm 0.83$ & $1.99 \pm 1.92$ \\
\hline & SS & & & & $0.40 \pm 0.47$ & $0.19 \pm 0.41$ & $2.13 \pm 2.17$ & $0.48 \pm 1.20$ & $2.33 \pm 1.54^{*}$ & $0.09 \pm 0.28$ \\
\hline & $\mathrm{R}$ & $0.00 \pm 0.00$ & $5.48 \pm 1.58^{*}$ & $10.02 \pm 3.91^{*}$ & $0.18 \pm 0.37$ & $0.35 \pm 0.46$ & $0.09 \pm 0.30$ & $0.50 \pm 1.27$ & $2.56 \pm 1.81^{*}$ & $2.10 \pm 2.07$ \\
\hline \multirow[t]{3}{*}{ Cyt. } & S & $0.00 \pm 0.00$ & $10.08 \pm 6.51^{*}$ & $2.09 \pm 4.05$ & $0.00 \pm 0.00$ & $1.79 \pm 3.59$ & $1.15 \pm 2.04$ & $3.58 \pm 5.26$ & $6.02 \pm 5.64^{*}$ & $1.41 \pm 2.58$ \\
\hline & SS & & & & $1.29 \pm 1.76$ & $0.57 \pm 1.81$ & $1.42 \pm 2.25$ & $0.00 \pm 0.00$ & $1.10 \pm 1.36$ & $0.08 \pm 0.26$ \\
\hline & $\mathrm{R}$ & $0.08 \pm 0.26$ & $7.35 \pm 4.81^{*}$ & $3.35 \pm 3.50$ & $0.46 \pm 0.67$ & $1.65 \pm 2.57$ & $0.10 \pm 0.32$ & $0.00 \pm 0.00$ & $1.15 \pm 1.41$ & $0.00 \pm 0.00$ \\
\hline \multirow[t]{5}{*}{ MI } & $\mathrm{S}$ & $178.84 \pm 48.31$ & $135.46 \pm 42.91$ & $178.05 \pm 70.38$ & $142.43 \pm 24.48$ & $137.88 \pm 29.09$ & $125.54 \pm 39.03$ & $126.24 \pm 29.89$ & $131.31 \pm 18.69$ & $97.88 \pm 10.96^{*}$ \\
\hline & SS & & & & $109.05 \pm 13.81^{*}$ & $114.95 \pm 20.47$ & $146.74 \pm 57.08$ & $151.88 \pm 39.09$ & $97.13 \pm 13.39^{*}$ & $145.94 \pm 29.33$ \\
\hline & $\mathrm{R}$ & $188.32 \pm 32.19$ & $126.26 \pm 5.55$ & $138.28 \pm 35.23$ & $120.46 \pm 17.70$ & $153.77 \pm 49.01$ & $147.07 \pm 41.81$ & $167.74 \pm 37.10$ & $176.73 \pm 37.32$ & $147.63 \pm 53.63^{\star}$ \\
\hline & & Controls & & & & $\mathrm{SCFC}+\mathrm{SCB}$ & & & & \\
\hline & & SC & SCBC & & & $5 \%$ & $10 \%$ & $25 \%$ & $50 \%$ & $75 \%$ \\
\hline \multirow{3}{*}{ Gen. } & S & $3.65 \pm 1.91$ & $1.44 \pm 0.74$ & & & $2.71 \pm 2.78$ & $2.10 \pm 2.61$ & $2.18 \pm 1.26$ & $2.94 \pm 1.56$ & $2.66 \pm 1.06$ \\
\hline & SS & $2.44 \pm 2.21$ & $3.54 \pm 1.93$ & & & $1.92 \pm 2.87$ & $1.69 \pm 1.26$ & $1.65 \pm 1.69$ & $2.50 \pm 2.57$ & $3.57 \pm 2.61$ \\
\hline & $\mathrm{R}$ & $2.67 \pm 1.91$ & $1.47 \pm 1.62$ & & & $1.10 \pm 1.22$ & $1.87 \pm 1.27$ & $1.33 \pm 1.16$ & $4.24 \pm 1.79^{*}$ & $5.69 \pm 4.32^{*}$ \\
\hline \multirow{3}{*}{ Mut. } & S & $0.42 \pm 0.71$ & $0.18 \pm 0.38$ & & & $0.70 \pm 0.38$ & $1.09 \pm 0.95$ & $1.32 \pm 1.30$ & $1.76 \pm 1.19$ & $2.91 \pm 1.61^{*}$ \\
\hline & SS & $0.53 \pm 0.74$ & $0.69 \pm 1.17$ & & & $0.43 \pm 0.72$ & $0.48 \pm 0.69$ & $0.08 \pm 0.24$ & $0.50 \pm 0.84$ & $2.15 \pm 2.12$ \\
\hline & $\mathrm{R}$ & $0.18 \pm 0.38$ & $0.18 \pm 0.58$ & & & $0.29 \pm 0.66$ & $0.08 \pm 0.26$ & $0.08 \pm 0.26$ & $0.19 \pm 0.41$ & $0.17 \pm 0.37$ \\
\hline \multirow[t]{3}{*}{ Cyt. } & S & $0.89 \pm 1.29$ & $0.18 \pm 0.39$ & & & $0.52 \pm 0.75$ & $0.85 \pm 1.97$ & $1.66 \pm 1.39$ & $0.00 \pm 0.00$ & $1.11 \pm 1.38$ \\
\hline & SS & $2.01 \pm 1.76$ & $1.43 \pm 2.57$ & & & $0.00 \pm 0.00$ & $0.00 \pm 0.00$ & $0.00 \pm 0.00$ & $0.00 \pm 0.00$ & $1.42 \pm 2.56$ \\
\hline & $\mathrm{R}$ & $3.27 \pm 3.76$ & $0.00 \pm 0.00$ & & & $0.10 \pm 0.31$ & $0.83 \pm 0.99$ & $1.07 \pm 3.12$ & $2.47 \pm 5.26$ & $1.38 \pm 1.37$ \\
\hline \multirow[t]{3}{*}{ MI } & $S$ & $132.32 \pm 15.49$ & $100.30 \pm 22.60^{*}$ & & & $147.91 \pm 20.80$ & $131.32 \pm 17.44$ & $123.08 \pm 21.35$ & $106.28 \pm 15.43^{*}$ & $98.46 \pm 14.65^{*}$ \\
\hline & SS & $93.84 \pm 8.07^{*}$ & $93.61 \pm 34.55^{*}$ & & & $126.11 \pm 40.48$ & $147.63 \pm 53.63$ & $176.76 \pm 37.10$ & $167.74 \pm 37.32$ & $124.25 \pm 21.74$ \\
\hline & $\mathrm{R}$ & $98.82 \pm 12.00^{\star}$ & $129.54 \pm 25.99$ & & & $129.82 \pm 36.58$ & $118.46 \pm 12.15$ & $105.12 \pm 16.67$ & $107.45 \pm 15.91^{\star}$ & $103.12 \pm 19.71^{\star}$ \\
\hline
\end{tabular}

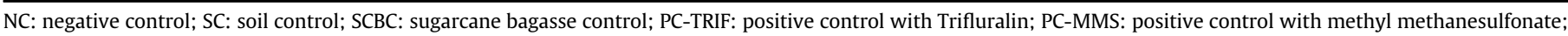

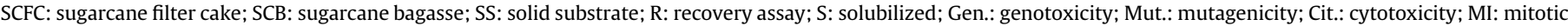

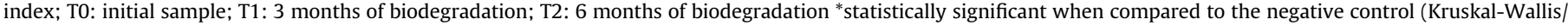
Dunn, $\mathrm{p}<0.05$ ); ${ }^{\star}$ statistically significant when compared to the negative control (One-Way ANOVA/Dunnet, $\mathrm{p}<0.05$ ).

through the process of biodegradation, which is a practice already used in several countries (Prado et al., 2013).

After 3 months of biodegradation (T1), a new batch of experiments was carried out and the results obtained were presented in Table 4. In this table is possible to note that SC and SCBC did not induce cell death, but in general they were capable of inhibiting cell division (MI). Tests performed with the solid form of the soil control (SC) showed that there was a decrease of MI, including after the recovery period. In relation to the SCBC, an inhibition of cell division was observed for the exposure done with the solid substrate and with the solubilized sample, but this effect was not registered after the recovery period. Note that the potentially cytotoxic substances present in the initial samples (TO) of SC and SCBC, did not suffer degradation after 3 months and continued affecting the development of the meristematic region of the $A$. cepa roots (Table 4).

In relation to the MI, several results with significant reduction were observed among the different exposures performed; such as for the solid substrates - 50\%-SCFC, 75\%-SCFC, 5\%-SCFC + SCB and $50 \%-S C F C+$ SCB; the solubilized samples - 50\%-SCFC, 75\%-SCFC, $100 \%-$ SCFC, $5 \%$-SCFC + SCB and 25\%-SCFC + SCB; and the samples after recovery time - 25\%-SCFC, 75\%-SCFC, $100 \%$-SCFC, $10 \%$ SCFC + SCB, 25\%-SCFC + SCB and 50\%-SCFC + SCB. When these results (T1) were compared with those obtained before the beginning of the biodegradation process (T0 - Table 3), it was observed a greater cytotoxic potential for samples obtained in T1. This may be due to the presence of cytotoxic substances, perhaps biodegradation by-products that has the capacity of inhibiting cell division of the plant.

SCB is a rich-based lignocellulose compound, identified as the major component of plant biomass, covering around half of the matter produced by photosynthesis. The main components of lignocellulose are cellulose, hemicellulose and lignin. Cellulose and hemicellulose are macromolecules synthesized from sugars and lignin is a polymeric phenolic structure, derived from phenylpropanoid precursors (Sánchez, 2009). Bugg et al. (2011) described that several microorganisms, like bacteria and fungi, are capable to degrade lignocellulose compounds, being lignin harder to mineralize. However, these same authors report that phenolic compounds appears as by-products during the process of biodegradation and, according to Raut et al. (2014), this class of chemical compounds has antimitotic action on A. cepa, inhibiting root growth due to MI reduction.

Regarding the number of cellular death, significant results were verified for the sample of $100 \%$-SCFC (solid substrate and solubilized) and for the sample of 75\%-SCFC + SCB (solubilized). Despite the association of $75 \%$-SCFC + SCB in its solid state did not induce cell death, there was cytotoxic effect after the recovery test.

A possible explanation for the inhibition caused on the meristem development may be related to the SCB biodegradation, because this by-product of sugarcane has the potential to adsorb metals and as the biodegradation occurs it could release these metals in the environment. Another explanation could be the biodegradation of lignin present in all plant cells, which generates phenolic compounds that may have toxic activity, as discussed before (Budziak et al., 2004; Conceição et al., 2005; Bolboacă and Jäntschi, 2014).

In relation to the criterion of genotoxicity, SC and the SCBC showed no significant values, when compared with the NC, i.e. showing an absence of agents capable to induce CA. Regarding the exposure to different associations, significant values were observed only after the recovery test for the associations of $25 \%$-SCFC, $50 \%$ - 
Table 4

Mean of cellular alterations observed in meristematic cells of $A$. cepa exposed to different treatments, during the degradation period ( 3 months - T1).

\begin{tabular}{|c|c|c|c|c|c|c|c|c|c|c|}
\hline & \multirow[t]{2}{*}{ Assay } & \multicolumn{3}{|l|}{ Controls } & \multicolumn{6}{|l|}{ SCFC } \\
\hline & & NC & PC-TRIF & PC-MMS & $5 \%$ & $10 \%$ & $25 \%$ & $50 \%$ & $75 \%$ & $100 \%$ \\
\hline \multirow[t]{3}{*}{ Gen. } & $\mathrm{S}$ & $0.78 \pm 0.76$ & $13.31 \pm 5.28^{*}$ & $9.42 \pm 4.94^{*}$ & $2.12 \pm 1.37$ & $1.81 \pm 1.29$ & $2.50 \pm 2.05$ & $2.22 \pm 2.76$ & $2.04 \pm 1.34$ & $1.62 \pm 0.80$ \\
\hline & SS & & & & $2.12 \pm 1.51$ & $2.63 \pm 2.18$ & $2.90 \pm 2.49$ & $2.67 \pm 2.39$ & $1.79 \pm 1.20$ & $2.37 \pm 1.72$ \\
\hline & $\mathrm{R}$ & $0.37 \pm 0.40$ & $12.35 \pm 5.10^{*}$ & $7.90 \pm 4.68^{*}$ & $2.48 \pm 1.49$ & $2.67 \pm 2.05$ & $3.34 \pm 2.67^{*}$ & $2.09 \pm 1.21$ & $1.33 \pm 1.19$ & $0.92 \pm 0.74$ \\
\hline \multirow[t]{3}{*}{ Mut. } & $\mathrm{S}$ & $0.30 \pm 0.48$ & $5.89 \pm 2.12^{*}$ & $12.71 \pm 7.70^{*}$ & $0.46 \pm 0.65$ & $0.38 \pm 0.64$ & $0.73 \pm 0.95$ & $1.13 \pm 0.97$ & $0.71 \pm 0.72$ & $0.09 \pm 0.29$ \\
\hline & SS & & & & $0.76 \pm 0.76$ & $0.00 \pm 0.00$ & $0.74 \pm 0.79$ & $0.73 \pm 0.74$ & $0.39 \pm 0.63$ & $0.81 \pm 0.79$ \\
\hline & $\mathrm{R}$ & $0.18 \pm 0.38$ & $3.40 \pm 1.95^{*}$ & $11.58 \pm 5.11^{*}$ & $0.45 \pm 0.62$ & $0.64 \pm 0.75$ & $0.75 \pm 0.89$ & $0.48 \pm 1.20$ & $0.09 \pm 0.28$ & $0.10 \pm 0.30$ \\
\hline \multirow[t]{3}{*}{ Cyt. } & $\mathrm{S}$ & $0.00 \pm 0.00$ & $10.20 \pm 6.60^{*}$ & $6.64 \pm 5.35^{*}$ & $0.68 \pm 1.32$ & $0.27 \pm 0.87$ & $0.64 \pm 0.74$ & $0.87 \pm 1.97$ & $2.61 \pm 2.89$ & $5.37 \pm 5.40^{*}$ \\
\hline & SS & & & & $0.96 \pm 1.29$ & $0.00 \pm 0.00$ & $0.00 \pm 0.00$ & $0.00 \pm 0.00$ & $3.46 \pm 4.46$ & $3.84 \pm 2.68^{*}$ \\
\hline & $\mathrm{R}$ & $0.00 \pm 0.00$ & $7.76 \pm 6.99^{*}$ & $5.01 \pm 9.65$ & $1.06 \pm 3.36$ & $2.22 \pm 4.83$ & $1.81 \pm 3.62$ & $0.00 \pm 0.00$ & $2.85 \pm 5.87$ & $0.00 \pm 0.00$ \\
\hline \multirow[t]{5}{*}{ MI } & $S$ & $178.84 \pm 48.31$ & $135.46 \pm 42.91$ & $178.05 \pm 70.38$ & $148.84 \pm 17.74$ & $137.73 \pm 26.50$ & $142.84 \pm 15.75$ & $122.70 \pm 27.06^{*}$ & $102.80 \pm 6.85^{*}$ & $126.53 \pm 34.21$ \\
\hline & SS & & & & $109.05 \pm 13.81$ & $114.95 \pm 20.47$ & $146.74 \pm 57.08$ & $105.80 \pm 21.22^{*}$ & $151.88 \pm 39.09^{*}$ & $145.94 \pm 29.33$ \\
\hline & $\mathrm{R}$ & $230.34 \pm 26.56$ & $109.91 \pm 19.63^{*}$ & $158.38 \pm 25.32$ & $151.04 \pm 32.62$ & $135.39 \pm 19.29$ & $127.86 \pm 34.97^{*}$ & $151.88 \pm 39.09$ & $91.13 \pm 13.39^{*}$ & $93.61 \pm 14.45^{*}$ \\
\hline & & Controls & & & & SCFC + SCB & & & & \\
\hline & & SC & SCBC & & & $5 \%$ & $10 \%$ & $25 \%$ & $\mathbf{5 0} \%$ & $75 \%$ \\
\hline \multirow[t]{3}{*}{ Gen. } & $S$ & $1.54 \pm 1.20$ & $1.09 \pm 1.19$ & & & $0.95 \pm 0.79$ & $1.85 \pm 1.24$ & $2.13 \pm 1.24$ & $2.21 \pm 1.52$ & $2.44 \pm 1.22$ \\
\hline & SS & $1.06 \pm 1.01$ & $1.96 \pm 1.20$ & & & $2.88 \pm 1.74$ & $2.40 \pm 1.80$ & $2.79 \pm 1.87$ & $3.52 \pm 2.43$ & $3.43 \pm 1.78$ \\
\hline & $\mathrm{R}$ & $2.20 \pm 1.48$ & $2.78 \pm 1.86$ & & & $2.32 \pm 2.02$ & $2.72 \pm 2.94$ & $2.67 \pm 1.53$ & $3.11 \pm 0.79^{*}$ & $4.36 \pm 2.02^{*}$ \\
\hline \multirow[t]{3}{*}{ Mut. } & $\mathrm{S}$ & $0.46 \pm 1.17$ & $0.26 \pm 0.58$ & & & $0.09 \pm 0.29$ & $0.67 \pm 1.29$ & $0.65 \pm 0.76$ & $1.24 \pm 1.09$ & $1.52 \pm 0.53^{*}$ \\
\hline & SS & $0.48 \pm 0.68$ & $2.17 \pm 2.29$ & & & $1.91 \pm 2.51$ & $0.00 \pm 0.00$ & $0.19 \pm 0.40$ & $1.85 \pm 2.05$ & $0.96 \pm 1.03$ \\
\hline & $\mathrm{R}$ & $0.46 \pm 0.67$ & $0.19 \pm 0.41$ & & & $0.37 \pm 0.48$ & $0.46 \pm 0.66$ & $0.65 \pm 0.99$ & $0.38 \pm 0.49$ & $0.19 \pm 0.41$ \\
\hline \multirow[t]{3}{*}{ Cyt. } & $S$ & $0.00 \pm 0.00$ & $0.00 \pm 0.00$ & & & $0.00 \pm 0.00$ & $0.00 \pm 0.00$ & $3.25 \pm 3.78$ & $0.00 \pm 0.00$ & $6.73 \pm 5.69^{*}$ \\
\hline & SS & $0.00 \pm 0.00$ & $0.00 \pm 0.00$ & & & $0.00 \pm 0.00$ & $0.00 \pm 0.00$ & $0.00 \pm 0.00$ & $1.55 \pm 2.82$ & $2.34 \pm 2.43$ \\
\hline & $\mathrm{R}$ & $0.20 \pm 0.63$ & $0.64 \pm 2.02$ & & & $0.09 \pm 0.29$ & $2.44 \pm 3.08$ & $3.15 \pm 3.03$ & $3.55 \pm 3.92$ & $5.64 \pm 4.09^{*}$ \\
\hline \multirow[t]{3}{*}{ MI } & $S$ & $127.47 \pm 30.61$ & $110.99 \pm 16.85^{*}$ & & & $112.09 \pm 12.71^{*}$ & $141.17 \pm 31.54$ & $123.34 \pm 22.12^{*}$ & $132.72 \pm 21.36$ & $136 . \overline{25} \pm 43.18$ \\
\hline & SS & $93.84 \pm 8.07$ & $97.97 \pm 12.92^{*}$ & & & $109.87 \pm 23.45^{*}$ & $123.53 \pm 18.19$ & $126.15 \pm 20.25$ & $102.68 \pm 28.59^{*}$ & $135.03 \pm 53.32$ \\
\hline & $\mathrm{R}$ & $133.53 \pm 18.69^{*}$ & $149.33 \pm 37.98$ & & & $142.44 \pm 30.90$ & $112.46 \pm 16.46^{*}$ & $109.11 \pm 28.04^{*}$ & $130.14 \pm 49.16^{*}$ & $178.84 \pm 48.31$ \\
\hline
\end{tabular}

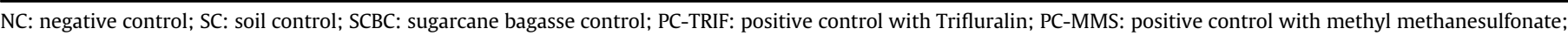

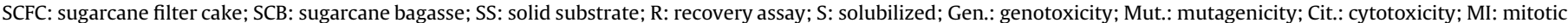

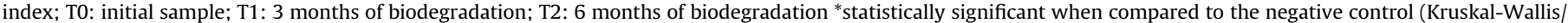
Dunn, $\mathrm{p}<0.05$ ).

SCFC + SCB and 75\%-SCFC + SCB. As a significant amount of CA was only observed after these treatments, we suggest that some substances may have become trapped in the seed and/or in the roots of A. cepa, which eventually caused such damage by the persistence of action. Probably, these substances would need a longer time of action to affect the test organism, as occurred in the recovery test after $48 \mathrm{~h}$.

Regarding the mutagenic potential, only the aqueous extract of the association of 75\%-SCFC + SCB presented significant amount of $\mathrm{MN}$. By this result, it is possible to infer that some substances present in SCFC and SCB, after the degradation for 3 months may have suffered a transformation, which changed its solubility from hydrophobic to hydrophilic, becoming able to penetrate the meristem and induce these changes. Besides the possibility of metals influencing the cell division, they can also cause specific chromosomal changes (Fiskesjö, 1988; Leme and Marin-Morales, 2009). Majer et al. (2002) mention that the availability of the compounds present in the soil depends on the acidity of the soil. These compounds could then induce genotoxic effects on organisms exposed, resulting in the induction of $\mathrm{MN}$, featuring mutagenicity. This is due to the fact of $\mathrm{pH}$ influencing the mobility of metal ions in addition to other factors, such as the particle size, the distribution and the carbon content of the soil. According to Kumari et al. (2011), nanoparticles of zinc oxide are clastogenic agents capable of inducing cytotoxic, genotoxic and mutagenic effects in living beings, confirmed by experiments performed with $A$. cepa. Thus, as the samples studied in this study showed metals and acidic $\mathrm{pH}$, the toxicity found may be related to these factors.

Furthermore, lead can affect the growth of the rootlets of various plants consumed by humans, including onion, which accumulates in the meristematic cells. Studies conducted by
Wierzbicka and Antosiewicz (1993) demonstrated that lead inhibited the growth of roots of 12 different species of plants at a rate of $5-36 \%$, by assessing concentrations varying from 1.0 to $20.0 \mu \mathrm{g} / \mathrm{mL}$. At least $96.6 \%$ of lead assimilated by plants was accumulated in root meristem, associated with the cell wall or stored in the vacuoles, demonstrating that humans can consume the lead that was present in the soil and accumulated in plants. Still, in the study conducted by Wierzbicka (1999), the author demonstrated that $A$. cepa is a species with average tolerance to lead exposure (tested with 2.5 and $5.0 \mu \mathrm{g} / \mathrm{mL}$ of $\mathrm{Pb}^{2+}$ ), whose cells do not die due to the accumulation of this metal, increasing the risk of transferring this metal by food, thus causing possible harm to human health.

Among the metals present in SCFC, cadmium (Cd) is the element that presents the major characteristics related to the inhibition of root growth and to the induction of $\mathrm{Ca}$ and $\mathrm{Mn}$. $\mathrm{Cd}$ has chemical characteristics similar to $\mathrm{Ca}^{2+}$ and $\mathrm{Zn}^{2+}$ and, due to that, enters in several chemical and biological processes, being able to change the calcium homeostasis in vivo, even in negligible environmental exposures (ŞAPLAKOĞ;LU and İ̧CAN, 1998).

Ünyayar and collaborators (2006) identified the cytotoxic and genotoxic potential of cadmium. In its work, the authors demonstrated that cadmium was able to induce micronuclei, delay in cell division, oxidative stress and inhibition of the MI in meristematic cells of A. sativum and Vicia faba, in a range of $1 \mathrm{mM}(\sim 0.2 \mathrm{mg} / \mathrm{mL})$ to $200 \mathrm{mM}(\sim 47.2 \mathrm{mg} / \mathrm{mL})$. Despite the metal effects did not present a significant dose-response relationship, the concentration and time of exposure to cadmium are important parameters to be considered in the changes in the plant growth and on the integrity of the cells. The authors also suggested that significant frequencies of MN may be a result of oxidative stress and that the highest concentrations of Cd (100 and $200 \mathrm{mM}$ ) were able to reduce significantly the MI. Seth 
Table 5

Mean of cellular alterations observed in meristematic cells of $A$. cepa exposed to different treatments, after the degradation period (6 months - T2).

\begin{tabular}{|c|c|c|c|c|c|c|c|c|c|c|}
\hline & \multirow[t]{2}{*}{ Assay } & \multicolumn{3}{|l|}{ Controls } & \multicolumn{6}{|l|}{ SCFC } \\
\hline & & NC & PC-TRF & PC-MMS & $5 \%$ & $10 \%$ & $25 \%$ & $50 \%$ & $75 \%$ & $100 \%$ \\
\hline \multirow[t]{3}{*}{ Gen. } & S & $1.94 \pm 1.49$ & $13.50 \pm 5.85^{*}$ & $5.81 \pm 5.67$ & $3.42 \pm 2.60$ & $2.70 \pm 1.73$ & $3.63 \pm 2.59$ & $2.09 \pm 1.21$ & $3.30 \pm 1.77$ & $1.70 \pm 0.88$ \\
\hline & SS & & & & $1.67 \pm 0.97$ & $3.50 \pm 2.24$ & $4.18 \pm 1.80$ & $5.31 \pm 1.44^{*}$ & $3.47 \pm 2.07$ & $2.96 \pm 1.91$ \\
\hline & $\mathrm{R}$ & $0.84 \pm 0.67$ & $10.03 \pm 7.17^{*}$ & $6.05 \pm 3.81^{*}$ & $1.18 \pm 0.84$ & $2.48 \pm 1.89$ & $1.76 \pm 0.93$ & $2.00 \pm 0.94$ & $1.42 \pm 0.97$ & $3.29 \pm 1.07^{*}$ \\
\hline \multirow[t]{3}{*}{ Mut. } & S & $0.08 \pm 0.25$ & $5.57 \pm 1.28^{*}$ & $15.26 \pm 6.49^{*}$ & $0.71 \pm 0.82$ & $0.19 \pm 0.41$ & $2.13 \pm 2.17$ & $0.48 \pm 1.20$ & $2.33 \pm 1.54$ & $0.09 \pm 0.28$ \\
\hline & SS & & & & $0.19 \pm 0.40$ & $0.81 \pm 1.19$ & $0.75 \pm 0.96$ & $0.37 \pm 0.65$ & $2.52 \pm 1.73^{*}$ & $0.36 \pm 0.46$ \\
\hline & $\mathrm{R}$ & $0.17 \pm 0.37$ & $6.32 \pm 2.59^{*}$ & $13.10 \pm 6.97^{*}$ & $0.53 \pm 0.61$ & $0.38 \pm 0.49$ & $0.09 \pm 0.29$ & $1.27 \pm 0.98$ & $0.66 \pm 0.78$ & $0.09 \pm 0.29$ \\
\hline \multirow[t]{3}{*}{ Cyt. } & S & $0.99 \pm 1.41$ & $5.05 \pm 5.99$ & $3.74 \pm 5.01$ & $1.19 \pm 2.21$ & $0.57 \pm 1.81$ & $1.42 \pm 2.25$ & $0.00 \pm 0.00$ & $1.10 \pm 1.36$ & $0.08 \pm 0.26$ \\
\hline & SS & & & & $0.00 \pm 0.00$ & $3.20 \pm 1.99$ & $1.56 \pm 2.64$ & $1.99 \pm 2.18$ & $1.09 \pm 1.39$ & $3.99 \pm 7.03$ \\
\hline & $\mathrm{R}$ & $0.25 \pm 0.81$ & $1.93 \pm 4.21$ & $4.24 \pm 5.93$ & $0.64 \pm 0.86$ & $0.62 \pm 0.74$ & $0.09 \pm 0.29$ & $1.10 \pm 0.98$ & $1.58 \pm 1.58$ & $2.03 \pm 1.02^{*}$ \\
\hline \multirow[t]{5}{*}{ MI } & S & $167.21 \pm 34.62$ & $142.63 \pm 129.54$ & $154.12 \pm 67.86$ & $109.85 \pm 13.91^{*}$ & $114.95 \pm 20.47$ & $146.74 \pm 57.08$ & $151.88 \pm 39.09$ & $91.13 \pm 13.39^{*}$ & $157 . \overline{12} \pm 51.68$ \\
\hline & SS & & & & $168.97 \pm 42.20$ & $109.79 \pm 15.94^{*}$ & $158.15 \pm 38.70$ & $148.70 \pm 37.92$ & $157.82 \pm 61.10$ & $125.96 \pm 19.80$ \\
\hline & $\mathrm{R}$ & $219.61 \pm 27.38$ & $179.03 \pm 69.64$ & $165.57 \pm 59.65$ & $164.38 \pm 24.38$ & $161.17 \pm 44.48$ & $170.12 \pm 30.96$ & $149.71 \pm 16.28$ & $120.12 \pm 26.08^{*}$ & $104.94 \pm 7.86^{*}$ \\
\hline & & Controls & & & & $\mathrm{SCFC}+\mathrm{SCB}$ & & & & \\
\hline & & SC & SCBC & & & $5 \%$ & $10 \%$ & $25 \%$ & $50 \%$ & $75 \%$ \\
\hline \multirow[t]{3}{*}{ Gen. } & $\mathrm{S}$ & $2.74 \pm 1.34$ & $1.96 \pm 1.45$ & & & $1.92 \pm 2.87$ & $1.22 \pm 1.49$ & $1.65 \pm 1.69$ & $2.50 \pm 2.57$ & $3.57 \pm 2.61$ \\
\hline & SS & $2.71 \pm 1.81$ & $2.75 \pm 1.95$ & & & $3.28 \pm 1.21$ & $3.53 \pm 2.57$ & $2.38 \pm 2.10$ & $2.91 \pm 2.13$ & $4.13 \pm 3.14$ \\
\hline & $\mathrm{R}$ & $2.46 \pm 1.41$ & $2.14 \pm 1.27$ & & & $2.17 \pm 1.27$ & $2.33 \pm 1.84$ & $1.81 \pm 1.85$ & $2.97 \pm 1.82$ & $3.18 \pm 2.18$ \\
\hline \multirow[t]{3}{*}{ Mut. } & S & $0.10 \pm 0.30$ & $2.17 \pm 2.29$ & & & $0.43 \pm 0.72$ & $0.30 \pm 0.67$ & $0.08 \pm 0.24$ & $0.50 \pm 0.84$ & $2.15 \pm 2.15$ \\
\hline & SS & $0.08 \pm 0.26$ & $0.35 \pm 0.46$ & & & $0.20 \pm 0.63$ & $0.67 \pm 0.93$ & $1.11 \pm 0.95$ & $0.56 \pm 1.01$ & $0.62 \pm 1.19$ \\
\hline & $\mathrm{R}$ & $1.12 \pm 0.76$ & $0.38 \pm 0.67$ & & & $0.57 \pm 0.93$ & $1.58 \pm 0.76$ & $0.17 \pm 0.35$ & $0.27 \pm 0.44$ & $0.55 \pm 0.48$ \\
\hline \multirow[t]{3}{*}{ Cyt. } & $S$ & $0.85 \pm 1.24$ & $0.00 \pm 0.00$ & & & $0.00 \pm 0.00$ & $0.00 \pm 0.00$ & $0.00 \pm 0.00$ & $0.00 \pm 0.00$ & $1.42 \pm 2.56$ \\
\hline & SS & $4.43 \pm 3.17$ & $2.88 \pm 2.83$ & & & $0.37 \pm 0.65$ & $1.11 \pm 1.69$ & $3.32 \pm 3.10$ & $0.81 \pm 0.97$ & $2.88 \pm 2.83$ \\
\hline & $\mathrm{R}$ & $4.47 \pm 4.84^{*}$ & $0.95 \pm 0.77$ & & & $1.90 \pm 1.18$ & $0.00 \pm 0.00$ & $1.27 \pm 1.60$ & $1.39 \pm 1.95$ & $0.84 \pm 1.22$ \\
\hline \multirow[t]{3}{*}{ MI } & S & $127.91 \pm 26.96$ & $97.97 \pm 12.92^{*}$ & & & $126.11 \pm 40.48$ & $147.63 \pm 53.63$ & $176.73 \pm 37.10$ & $167.74 \pm 37.32$ & $124.25 \pm 21.74$ \\
\hline & SS & $170.84 \pm 36.52$ & $121.39 \pm 31.6$ & & & $155.93 \pm 29.12$ & $130.20 \pm 36.88$ & $131.08 \pm 31.60$ & $131.96 \pm 20.08$ & $121.39 \pm 20.53$ \\
\hline & $\mathrm{R}$ & $103.74 \pm 12.03^{*}$ & $137.49 \pm 19.90^{*}$ & & & $134.76 \pm 24.33^{*}$ & $138.83 \pm 16.57^{*}$ & $112.03 \pm 35.05^{*}$ & $138.12 \pm 57.27^{*}$ & $145.91 \pm 31.89$ \\
\hline
\end{tabular}

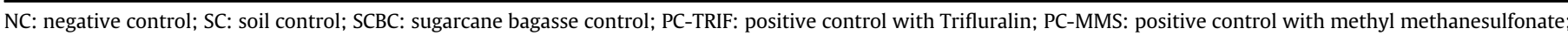

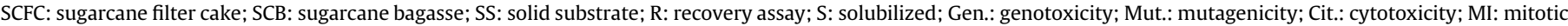

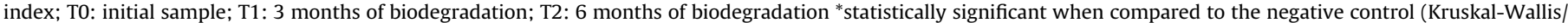
Dunn, $\mathrm{p}<0.05$ )

et al. (2008) found similar results when assessing the genotoxicity of Cd on A. cepa. These authors correlate the mitotic instability to the action of cadmium on the spindles, inhibiting the mitotic division and also inducing the formation of some types of CA. Still, these same authors suggest that Cd could damage the DNA, by indirect pathways, caused by the formation of reactive oxygen species, like superoxide $\left(\bullet \mathrm{O}_{2}^{-}\right)$and hydrogen peroxide $\left(\mathrm{H}_{2} \mathrm{O}_{2}\right)$, that generate oxidative stress; this same effect was observed by Ünyayar et al. (2006). Still in their study, Seth et al. (2008) demonstrated that after $24 \mathrm{~h}$ of recovery, there was a decline in the means of all endpoints. According to the authors, this reduction would be associated to a detoxification process performed by the plant, by means of the synthesis of chemical substances capable of chelating the toxic metal present in cell vacuoles.

Cd can cause inhibition of the root growth by decreasing the mitotic activity and DNA synthesis, even at low concentrations $\left(\geq 2.5 \mu \mathrm{M}\right.$ of $\mathrm{CdCl}_{2}$ ). These factors are directly related to elongation of the radicular tip. Related to these characteristics, Cd promotes changes in the microtubules or in the proteins associated with it, interfering in the cytoskeleton integrity and consequently in the integrity of the cell (Fusconi et al., 2007).

By the presentation of the results obtained in the present study, after a period of biodegradation (T1), it is observed that, as established for the initial samples, the lowest concentrations of SCFC could be applied in farmable soil without harming the crop and/or the local biota.

After 6 months of the biodegradation performed with the associations assessed in this study, a last phase (T2) of seeds exposure was performed. The results obtained for T2 are shown in Table 5.

About the criterion of cytotoxicity, it was possible observe that SC and SCBC showed evidences of cell death and inhibition of cell division again. The solubilized sample of SCBC was able to significantly reduce the MI. After the recovery test, only the SC induced significant mean of cell death, but both presented inhibition of MI. In relation to the tested samples, the pure SCFC (100\%SCFC) was the only one able to induce cell death after the recovery test. However, in relation to the MI, several significant reductions were observed: solubilized samples (5\%-SCFC and 75\%-SCFC); solid substrates before (10\%-SCFC) and after the recovery period (75\%SCFC; $100 \%$-SCFC; $5 \%$-SCFC + SCB; $10 \%$-SCFC + SCB; $25 \%-$ SCFC + SCB; 50\%-SCFC + SCB). From the results obtained after 6 months of biodegradation it was not possible to determine a dosedependent trend for the cytotoxicity induced by the samples. However, it is possible to note more frequent effects after the period of recovery, which may be related to the persistence of some substance with cytotoxic characteristics.

From these results and those presented in Tables 3 and 4, it is evident that both the SC and SCBC have some effect or component that is responsible for inhibiting cell division in the root meristem of $A$. cepa, reducing its MI, thus characterizing the soil and the bagasse as cytotoxic.

By the results obtained regarding the induction of $\mathrm{CA}$, it is observed a genotoxic potential for the association of 50\%-SCFC in the form of solid substrate and for the pure sample of SCFC (100\%SCFC), after the recovery test. However, the genotoxic damage recorded was not persistent and fixed in cells, since there were not observed significant values of MN for these associations. Furthermore, the solid form of the association of 75\%-SCFC, despite not having presented significant result of $\mathrm{CA}$, was the only treatment that induced the formation of significant mean of MN. Bhat et al (2014) evidenced a genotoxicity reduction for SCFC after 15 days of vermicompost. Despite the reduction observed, a tenfold frequency of chromosomal aberration was registered for the higher concentration of pressmud when compared to the negative control. 
Table 6

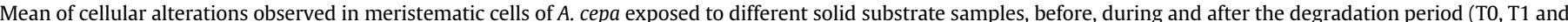
T2).

\begin{tabular}{|c|c|c|c|c|c|c|c|c|c|c|}
\hline & \multirow[t]{2}{*}{ Period } & \multicolumn{3}{|l|}{ Controls } & \multicolumn{6}{|l|}{ SCFC } \\
\hline & & NC & PC-TRIF & PC-MMS & $5 \%$ & $10 \%$ & $25 \%$ & $50 \%$ & $75 \%$ & $100 \%$ \\
\hline \multirow[t]{3}{*}{ Gen. } & T0 & $0.96 \pm 0.79$ & $13.20 \pm 5.22^{*}$ & $6.89 \pm 3.70^{*}$ & $2.39 \pm 1.49$ & $2.70 \pm 1.73$ & $3.63 \pm 2.59$ & $2.09 \pm 1.21$ & $3.30 \pm 1.70$ & $1.70 \pm 0.88$ \\
\hline & $\mathrm{T} 1$ & $0.78 \pm 0.76$ & $13.31 \pm 5.28 *$ & $9.42 \pm 4.94^{*}$ & $2.12 \pm 1.51$ & $2.63 \pm 2.18$ & $2.90 \pm 2.49$ & $2.67 \pm 2.39$ & $1.79 \pm 1.20$ & $2.37 \pm 1.72$ \\
\hline & $\mathrm{T} 2$ & $1.94 \pm 1.49$ & $13.50 \pm 5.85^{*}$ & $5.81 \pm 5.67$ & $1.67 \pm 0.97$ & $3.50 \pm 2.24$ & $4.18 \pm 1.80$ & $5.31 \pm 1.44^{*}$ & $3.47 \pm 2.07$ & $2.96 \pm 1.91$ \\
\hline \multirow[t]{3}{*}{ Mut. } & T0 & $0.09 \pm 0.27$ & $5.78 \pm 1.71^{*}$ & $15.36 \pm 5.56^{*}$ & $0.40 \pm 0.47$ & $0.19 \pm 0.41$ & $2.13 \pm 2.17$ & $0.48 \pm 1.20$ & $2.33 \pm 1.54^{*}$ & $0.09 \pm 0.28$ \\
\hline & $\mathrm{T} 1$ & $0.30 \pm 0.48$ & $5.89 \pm 2.12^{*}$ & $12.71 \pm 7.70^{*}$ & $0.76 \pm 0.76$ & $0.00 \pm 0.00$ & $0.74 \pm 0.79$ & $0.73 \pm 0.74$ & $0.39 \pm 0.63$ & $0.81 \pm 0.79$ \\
\hline & $\mathrm{T} 2$ & $0.08 \pm 0.25$ & $5.57 \pm 1.28^{*}$ & $15.26 \pm 6.49^{*}$ & $0.19 \pm 0.40$ & $0.81 \pm 1.19$ & $0.75 \pm 0.96$ & $0.37 \pm 0.65$ & $2.52 \pm 1.73^{*}$ & $0.36 \pm 0.46$ \\
\hline \multirow[t]{3}{*}{ Cyt. } & T0 & $0.00 \pm 0.00$ & $10.08 \pm 6.51^{*}$ & $2.09 \pm 4.05$ & $1.29 \pm 1.76$ & $0.57 \pm 1.81$ & $1.42 \pm 2.25$ & $0.00 \pm 0.00$ & $1.10 \pm 1.36$ & $0.08 \pm 0.26$ \\
\hline & $\mathrm{T} 1$ & $0.00 \pm 0.00$ & $10.20 \pm 6.60^{*}$ & $6.64 \pm 5.35^{*}$ & $0.96 \pm 1.29$ & $0.00 \pm 0.00$ & $0.00 \pm 0.00$ & $0.00 \pm 0.00$ & $3.46 \pm 4.46$ & $3.84 \pm 2.68^{*}$ \\
\hline & $\mathrm{T} 2$ & $0.99 \pm 1.41$ & $5.05 \pm 5.99$ & $3.74 \pm 5.01$ & $0.64 \pm 0.86$ & $0.62 \pm 0.74$ & $0.09 \pm 0.29$ & $1.10 \pm 0.98$ & $1.58 \pm 1.58$ & $2.03 \pm 1.02^{*}$ \\
\hline \multirow[t]{5}{*}{ MI } & T0 & $178.84 \pm 48.31$ & $135.46 \pm 42.91$ & $178.05 \pm 70.38$ & $109.05 \pm 13.81^{*}$ & $114.95 \pm 20.47$ & $146.74 \pm 57.08$ & $151.88 \pm 39.09$ & $97.13 \pm 13.39^{*}$ & $145.94 \pm 29.33$ \\
\hline & $\mathrm{T} 1$ & $180.23 \pm 38.83$ & $143.93 \pm 22.09$ & $157.12 \pm 51.68$ & $132.92 \pm 25.91$ & $161.53 \pm 23.83$ & $145.93 \pm 23.32$ & $105.80 \pm 21.22^{*}$ & $110.81 \pm 10.85^{*}$ & $125.15 \pm 25.14$ \\
\hline & $\mathrm{T} 2$ & $167.21 \pm 34.62$ & $142.63 \pm 129.54$ & $154.12 \pm 67.86$ & $168.97 \pm 42.20$ & $109.79 \pm 15.94^{*}$ & $158.15 \pm 38.70$ & $148.70 \pm 37.92$ & $157.82 \pm 61.10$ & $125.96 \pm 19.80$ \\
\hline & & \multicolumn{2}{|l|}{ Controls } & & & \multicolumn{5}{|l|}{$\mathrm{SCFC}+\mathrm{SCB}$} \\
\hline & & SC & $\mathrm{SCBC}$ & & & $5 \%$ & $10 \%$ & $25 \%$ & $50 \%$ & $75 \%$ \\
\hline \multirow[t]{3}{*}{ Gen. } & T0 & $2.44 \pm 2.21$ & $3.54 \pm 1.93$ & & & $1.92 \pm 2.87$ & $1.69 \pm 1.26$ & $1.65 \pm 1.69$ & $2.50 \pm 2.57$ & $3.57 \pm 2.61$ \\
\hline & $\mathrm{T} 1$ & $1.06 \pm 1.01$ & $1.96 \pm 1.20$ & & & $2.88 \pm 1.74$ & $2.40 \pm 1.80$ & $2.79 \pm 1.87$ & $3.52 \pm 2.43$ & $3.43 \pm 1.78$ \\
\hline & $\mathrm{T} 2$ & $2.71 \pm 1.81$ & $2.75 \pm 1.95$ & & & $3.28 \pm 1.21$ & $3.53 \pm 2.57$ & $2.38 \pm 2.10$ & $2.91 \pm 2.13$ & $4.13 \pm 3.14$ \\
\hline \multirow[t]{3}{*}{ Mut. } & T0 & $0.53 \pm 0.74$ & $0.69 \pm 1.17$ & & & $0.43 \pm 0.72$ & $0.48 \pm 0.69$ & $0.08 \pm 0.24$ & $0.50 \pm 0.84$ & $2.15 \pm 2.12$ \\
\hline & $\mathrm{T} 1$ & $0.48 \pm 0.68$ & $2.17 \pm 2.29$ & & & $1.91 \pm 2.51$ & $0.00 \pm 0.00$ & $0.19 \pm 0.40$ & $1.85 \pm 2.05$ & $0.96 \pm 1.03$ \\
\hline & $\mathrm{T} 2$ & $0.08 \pm 0.26$ & $0.35 \pm 0.46$ & & & $0.20 \pm 0.63$ & $0.67 \pm 0.93$ & $1.11 \pm 0.95$ & $0.56 \pm 1.01$ & $0.62 \pm 1.19$ \\
\hline \multirow[t]{3}{*}{ Cyt. } & T0 & $2.01 \pm 1.76$ & $1.43 \pm 2.57$ & & & $0.00 \pm 0.00$ & $0.00 \pm 0.00$ & $0.00 \pm 0.00$ & $0.00 \pm 0.00$ & $1.42 \pm 2.56$ \\
\hline & $\mathrm{T} 1$ & $0.00 \pm 0.00$ & $0.00 \pm 0.00$ & & & $0.00 \pm 0.00$ & $0.00 \pm 0.00$ & $0.00 \pm 0.00$ & $1.55 \pm 2.82$ & $2.34 \pm 2.43$ \\
\hline & $\mathrm{T} 2$ & $4.43 \pm 3.17$ & $2.88 \pm 2.83$ & & & $0.37 \pm 0.65$ & $1.11 \pm 1.69$ & $3.32 \pm 3.10$ & $0.81 \pm 0.97$ & $2.88 \pm 2.83$ \\
\hline \multirow[t]{3}{*}{ MI } & T0 & $93.84 \pm 8.07^{*}$ & $93.61 \pm 34.55^{*}$ & & & $126.11 \pm 40.48$ & $147.63 \pm 53.63$ & $176.76 \pm 37.10$ & $167.74 \pm 37.32$ & $124.25 \pm 21.74$ \\
\hline & $\mathrm{T} 1$ & $180.33 \pm 43.58$ & $97.97 \pm 12.92 *$ & & & $109.87 \pm 23.45^{*}$ & $123.53 \pm 18.19$ & $126.15 \pm 20.25$ & $102.68 \pm 28.59^{*}$ & $135.03 \pm 53.32$ \\
\hline & $\mathrm{T} 2$ & $170.84 \pm 36.52$ & $121.39 \pm 31.6$ & & & $155.93 \pm 29.12$ & $130.20 \pm 36.88$ & $131.08 \pm 31.60$ & $131.96 \pm 20.08$ & $121.39 \pm 20.53$ \\
\hline
\end{tabular}

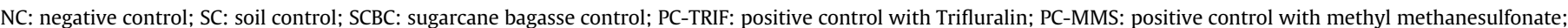

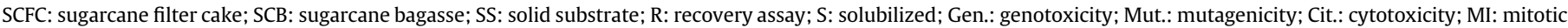

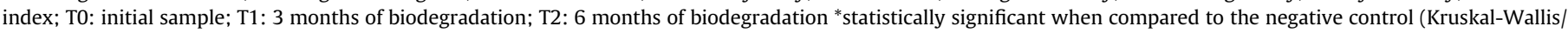
Dunn, $\mathrm{p}<0.05$ ).

These results indicate that only the lowest concentrations of SCFC could be used in agriculture in a safe manner because even after a period of 6 months of biodegradation, similar to the one that could occur in the field, the associations of higher concentrations of SCFC were still capable of inducing CA and MN. Moreover, we suggest that the SCB has had an important role to decrease the harmful potential of SCFC by easing its biodegradation, as described by Partha and Sivasubramanian (2006). At times T0 and T1, the associations based in larger quantities of SCFC were able to interact with the cells, damaging their genetic material, even when associated to the SCB. However, after the biodegradation of samples formed by SCFC associated to soil and SCB at time T2, this damage was not observed.

Aiming to evaluate the efficiency of biodegradation of SCFC by soil biota, were compared also the cytotoxic, genotoxic and mutagenic effects after the exposure to different treatments in relation to the time of biodegradation (T0, T1 and $\mathrm{T} 2$ ), as shown in Tables 6-8.

Regarding the solids substrates, it is possible to observe that the associations with the smallest quantities of SCFC (5\%,10\% and $25 \%$ ), with or without the addition of SCB, did not induce any harmful effects to the test organism $A$. cepa, making them capable of use safely in agriculture, based on the criteria evaluated in this study (Table 6). The period of biodegradation of 3 months (T1) showed an increase in the cytotoxic potential of the samples, when compared to T0. However, after 6 months of biodegradation this potential seems to be reduced, similar to the characteristics of the initial sample. It can be inferred that the SCB also helped in the process of mitigating the effects of SCFC, either by the adsorption of possible toxic substances or by enhancing the biodegradation of SCFC, since none of the associations formulated with the SCFC and the SCB presented induction of genotoxic and/or mutagenic damage in any of the times tested.

Despite the good results obtained by the solid substrates, after the recovery test the results changed significantly (Table 7). Despite the lack of genotoxicity and mutagenicity by the solid substrates (Table 6), when the roots were submitted to the recovery assay in ultrapure water for $48 \mathrm{~h}$, it seems to have been a loss in the integrity of the meristematic cells. Still, it is observed that as the biodegradation occurred, those associations formed by SCFC with SCB had its cytotoxic potential increased. Probably, there are substances in SCFC that require a longer time to induce changes in cells of $A$. cepa. Further, may have occurred the dissolution of substances adsorbed in rootlets by the ultrapure water used for the recovery test, which could have facilitated the influence on the root meristem. It is important to emphasize that, after undergoing biodegradation by 6 months (T2), just the pure SCFC sample (100\%-SCFC) presented genotoxic potential even after the recovery test, i.e. the process seems to have been efficient in the elimination of substances present in associations with lower amounts of SCFC, and that could interact with living organisms.

About the experiments carried out with the solubilized samples, damages are observed only for the highest concentrations of SCFC, especially present in 75\%-SCFC, $100 \%$-SCFC and 75\%-SCFC + SCB (Table 8). The associations with minor quantities of SCFC did not induce damages to the meristematic cells, independent on the time of biodegradation. These results indicate that small amounts of SCFC, with or without the SCB, could be used safely in crops because the aqueous extract or leachate tested does not seem to impact the environment. 
Table 7

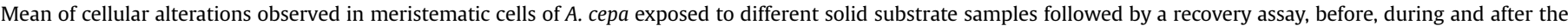
degradation period (T0, T1 and T2).

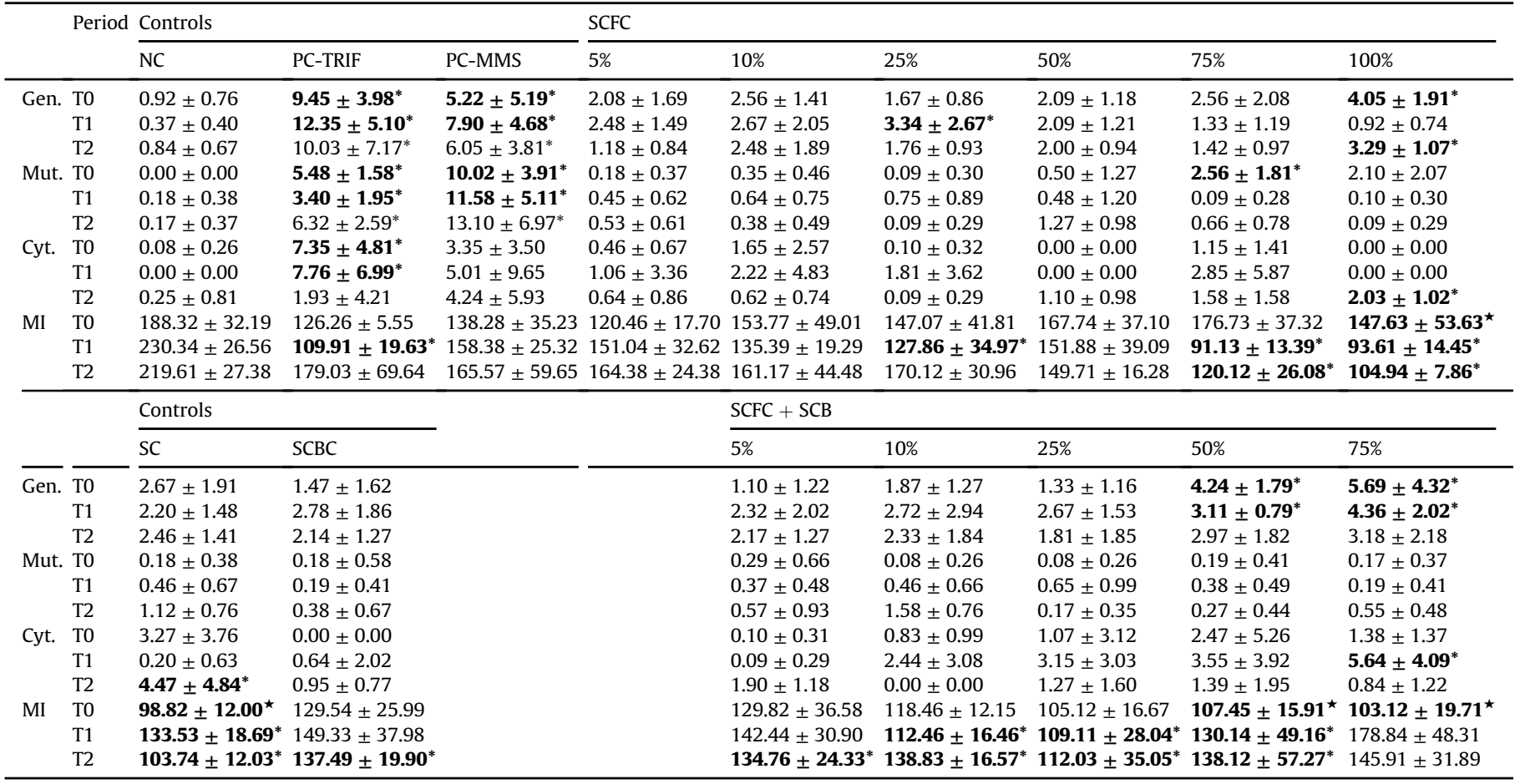

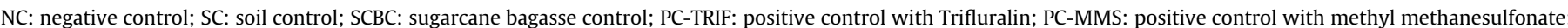

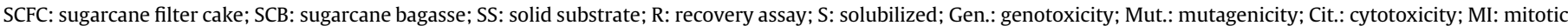

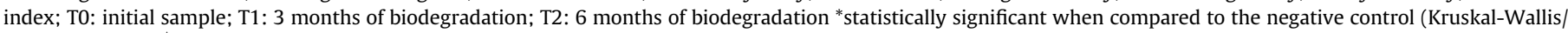
Dunn, $\mathrm{p}<0.05$ ); ${ }^{\star}$ statistically significant when compared to the negative control (One-Way ANOVA/Dunnet, $\mathrm{p}<0.05$ ).

Table 8

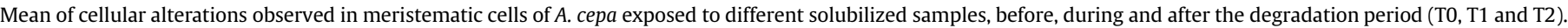

\begin{tabular}{|c|c|c|c|c|c|c|c|c|c|c|}
\hline & \multirow[t]{2}{*}{ Period } & \multicolumn{3}{|l|}{ Controls } & \multicolumn{6}{|l|}{ SCFC } \\
\hline & & NC & PC-TRIF & PC-MMS & $5 \%$ & $10 \%$ & $25 \%$ & $50 \%$ & $75 \%$ & $100 \%$ \\
\hline \multirow[t]{3}{*}{ Gen. } & T0 & $0.96 \pm 0.79$ & $13.20 \pm 5.22^{*}$ & $6.89 \pm 3.70^{*}$ & $1.55 \pm 1.26$ & $2.07 \pm 1.33$ & $2.88 \pm 1.61$ & $2.02 \pm 1.11$ & $2.19 \pm 1.57$ & $3.30 \pm 2.42$ \\
\hline & $\mathrm{T} 1$ & $0.78 \pm 0.76$ & $13.31 \pm 5.28^{*}$ & $9.42 \pm 4.94^{*}$ & $2.12 \pm 1.37$ & $1.81 \pm 1.29$ & $2.50 \pm 2.05$ & $2.22 \pm 2.76$ & $2.04 \pm 1.34$ & $1.62 \pm 0.80$ \\
\hline & $\mathrm{T} 2$ & $1.94 \pm 1.49$ & $13.50 \pm 5.85^{*}$ & $5.81 \pm 5.67$ & $3.42 \pm 2.60$ & $2.70 \pm 1.73$ & $3.63 \pm 2.59$ & $2.09 \pm 1.21$ & $3.30 \pm 1.77$ & $1.70 \pm 0.88$ \\
\hline \multirow[t]{3}{*}{ Mut. } & T0 & $0.09 \pm 0.27$ & $5.78 \pm 1.71^{*}$ & $15.36 \pm 5.56^{*}$ & $0.47 \pm 1.23$ & $0.63 \pm 0.73$ & $0.56 \pm 0.49$ & $1.28 \pm 0.64$ & $0.93 \pm 0.83$ & $1.99 \pm 1.92$ \\
\hline & $\mathrm{T} 1$ & $0.30 \pm 0.48$ & $5.89 \pm 2.12^{*}$ & $12.71 \pm 7.70^{*}$ & $0.46 \pm 0.65$ & $0.38 \pm 0.64$ & $0.73 \pm 0.95$ & $1.13 \pm 0.97$ & $0.71 \pm 0.72$ & $0.09 \pm 0.29$ \\
\hline & $\mathrm{T} 2$ & $0.08 \pm 0.25$ & $5.57 \pm 1.28^{*}$ & $15.26 \pm 6.49^{*}$ & $0.71 \pm 0.82$ & $0.19 \pm 0.41$ & $2.13 \pm 2.17$ & $0.48 \pm 1.20$ & $2.33 \pm 1.54$ & $0.09 \pm 0.28$ \\
\hline \multirow[t]{3}{*}{ Cyt. } & T0 & $0.00 \pm 0.00$ & $10.08 \pm 6.51^{*}$ & $2.09 \pm 4.05$ & $0.00 \pm 0.00$ & $1.79 \pm 3.59$ & $1.15 \pm 2.04$ & $3.58 \pm 5.26$ & $6.02 \pm 5.64^{*}$ & $1.41 \pm 2.58$ \\
\hline & $\mathrm{T} 1$ & $0.00 \pm 0.00$ & $10.20 \pm 6.60^{*}$ & $6.64 \pm 5.35^{*}$ & $0.68 \pm 1.32$ & $0.27 \pm 0.87$ & $0.64 \pm 0.74$ & $0.87 \pm 1.97$ & $2.61 \pm 2.89$ & $5.37 \pm 5.40^{*}$ \\
\hline & $\mathrm{T} 2$ & $0.99 \pm 1.41$ & $5.05 \pm 5.99$ & $3.74 \pm 5.01$ & $1.19 \pm 2.21$ & $0.57 \pm 1.81$ & $1.42 \pm 2.25$ & $0.00 \pm 0.00$ & $1.10 \pm 1.36$ & $0.08 \pm 0.26$ \\
\hline \multirow[t]{5}{*}{ MI } & T0 & $178.84 \pm 48.31$ & $135.46 \pm 42.91$ & $178.05 \pm 70.38$ & $142.43 \pm 24.48$ & $137.88 \pm 29.09$ & $125.54 \pm 39.03$ & $126.24 \pm 29.89$ & $131.31 \pm 18.69$ & $97.88 \pm 10.96^{*}$ \\
\hline & $\mathrm{T} 1$ & $171.64 \pm 25.06$ & $182.96 \pm 11.94$ & $130.99 \pm 20.37$ & $148.84 \pm 17.74$ & $137.73 \pm 26.50$ & $142.84 \pm 15.75$ & $122.70 \pm 27.06^{*}$ & $102.80 \pm 6.85^{*}$ & $126.53 \pm 34.21^{*}$ \\
\hline & $\mathrm{T} 2$ & $167.21 \pm 34.62$ & $142.63 \pm 129.54$ & $154.12 \pm 67.86$ & $109.85 \pm 13.91^{*}$ & $114.95 \pm 20.47$ & $146.74 \pm 57.08$ & $151.88 \pm 39.09$ & $91.13 \pm 13.39^{*}$ & $157.12 \pm 51.68$ \\
\hline & & \multicolumn{2}{|c|}{ Controls } & & & \multicolumn{5}{|l|}{$\mathrm{SCFC}+\mathrm{SCB}$} \\
\hline & & $\mathrm{SC}$ & $\mathrm{SCBC}$ & & & $5 \%$ & $10 \%$ & $25 \%$ & $50 \%$ & $75 \%$ \\
\hline \multirow[t]{3}{*}{ Gen. } & T0 & $3.65 \pm 1.91$ & $1.44 \pm 0.74$ & & & $2.71 \pm 2.78$ & $2.10 \pm 2.61$ & $2.18 \pm 1.26$ & $2.94 \pm 1.56$ & $2.66 \pm 1.06$ \\
\hline & $\mathrm{T} 1$ & $1.54 \pm 1.20$ & $1.09 \pm 1.19$ & & & $0.95 \pm 0.79$ & $1.85 \pm 1.24$ & $2.13 \pm 1.24$ & $2.21 \pm 1.52$ & $2.44 \pm 1.22$ \\
\hline & $\mathrm{T} 2$ & $2.74 \pm 1.34$ & $1.96 \pm 1.45$ & & & $1.92 \pm 2.87$ & $1.22 \pm 1.49$ & $1.65 \pm 1.69$ & $2.50 \pm 2.57$ & $3.57 \pm 2.61$ \\
\hline \multirow[t]{3}{*}{ Mut. } & T0 & $0.42 \pm 0.71$ & $0.18 \pm 0.38$ & & & $0.70 \pm 0.38$ & $1.09 \pm 0.95$ & $1.32 \pm 1.30$ & $1.76 \pm 1.19$ & $2.91 \pm 1.61^{*}$ \\
\hline & $\mathrm{T} 1$ & $0.46 \pm 1.17$ & $0.26 \pm 0.58$ & & & $0.09 \pm 0.29$ & $0.67 \pm 1.29$ & $0.65 \pm 0.76$ & $1.24 \pm 1.09$ & $1.52 \pm 0.53^{*}$ \\
\hline & $\mathrm{T} 2$ & $0.10 \pm 0.30$ & $2.17 \pm 2.29$ & & & $0.43 \pm 0.72$ & $0.30 \pm 0.67$ & $0.08 \pm 0.24$ & $0.50 \pm 0.84$ & $2.15 \pm 2.15$ \\
\hline \multirow[t]{3}{*}{ Cyt. } & T0 & $0.89 \pm 1.29$ & $0.18 \pm 0.39$ & & & $0.52 \pm 0.75$ & $0.85 \pm 1.97$ & $1.66 \pm 1.39$ & $0.00 \pm 0.00$ & $1.11 \pm 1.38$ \\
\hline & $\mathrm{T} 1$ & $0.00 \pm 0.00$ & $0.00 \pm 0.00$ & & & $0.00 \pm 0.00$ & $0.00 \pm 0.00$ & $3.25 \pm 3.78$ & $0.00 \pm 0.00$ & $6.73 \pm 5.69^{*}$ \\
\hline & $\mathrm{T} 2$ & $0.85 \pm 1.24$ & $0.00 \pm 0.00$ & & & $0.00 \pm 0.00$ & $0.00 \pm 0.00$ & $0.00 \pm 0.00$ & $0.00 \pm 0.00$ & $1.42 \pm 2.56$ \\
\hline \multirow[t]{3}{*}{ MI } & T0 & $132.32 \pm 15.49$ & $100.30 \pm 22.60^{*}$ & & & $147.91 \pm 20.80$ & $131.32 \pm 17.44$ & $123.08 \pm 21.35$ & $106.28 \pm 15.43^{*}$ & $98.46 \pm 14.65^{*}$ \\
\hline & $\mathrm{T} 1$ & $127.47 \pm 30.61$ & $110.99 \pm 16.85^{*}$ & & & $112.09 \pm 12.71^{*}$ & $141.17 \pm 31.54$ & $123.34 \pm 22.12^{*}$ & $132.72 \pm 21.36$ & $136.25 \pm 43.18$ \\
\hline & $\mathrm{T} 2$ & $127.91 \pm 26.96$ & $97.97 \pm 12.92^{*}$ & & & $126.11 \pm 40.48$ & $147.63 \pm 53.63$ & $176.73 \pm 37.10$ & $167.74 \pm 37.32$ & $124.25 \pm 21.74$ \\
\hline
\end{tabular}

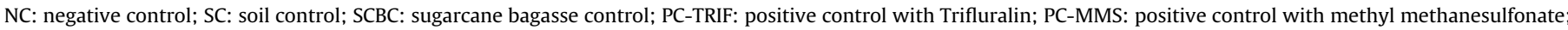

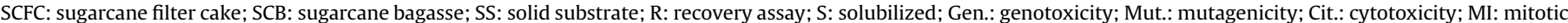

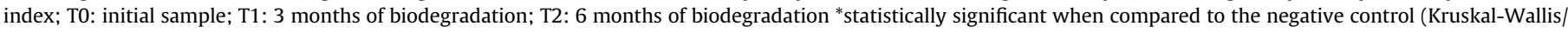
Dunn, $\mathrm{p}<0.05$ ). 


\section{Conclusions}

Many studies have been conducted in order to validate the use of SCFC as natural fertilizer of soils. The majority of them analyzes the chemical composition of the associations of SCFC in soil and evaluates the effects of these associations on the productivity of crops cultivated in fields fertilized by it. However, few studies have been conducted to evaluate the effects of these associations on the biota present on the application site.

By the results obtained in this study, we can recommend SCFC as a fertilizer only when used in small proportions in relation to the total amount of soil, associated or not with concomitant application of SCB. In spite of its rich content in metals, low quantities of SCFC were not capable of inducing significant genotoxic and mutagenic damage in the meristematic cells of $A$. cepa. Also, the potential of plants to accumulate these metals must be highlighted as these crops are inserted in the food chain and may reach the humans or be direct consumed by them.

The biodegradation process seems to be partially efficient because, beside the cytotoxic potential, the genotoxic and mutagenic potentials exhibited by associations with the highest concentrations of SCFC decreased after 6 months of natural attenuation. When compared with the associations in the form of solid substrates and without biodegradation (T0), the samples of T1 seem to have induced a greater amount of damage; perhaps by formation of metabolites, whose activity induces the formation of $\mathrm{CA}$ and $\mathrm{MN}$ in the cells. However, the process of biodegradation was maintained for a total of 6 months (T2), which allowed the reduction of this activity, i.e. the elimination of toxic metabolites by the possible degradation by the microbiota present in the samples.

By the analysis of the results, it was also possible to determine that the presence of SCB positively influenced the process of biodegradation. The associations composed by this residue, even with larger quantities of SCFC, presented greater reduction of genotoxicity and mutagenicity.

Finally, aiming the safe application of these by-products of sugarcane industry in crops, the mixtures that had the best results are those with less than $25 \%$ of SCFC associated or not with SCB, only after 6 months of natural attenuation because this period was essential to reduce waste genotoxicity.

The tests with $A$. cepa proved to be effective to evaluate the cytotoxic, genotoxic and mutagenic effects of SCFC, before and after a period of biodegradation. In addition, the biodegradation by 6 months showed to be efficient for the reduction of the toxicity of SCFC, even in their associations with high quantities, making its use in agriculture more secure. Finally, it should be emphasized that despite the associations with lower quantities of SCFC did not cause harmful effects to the test organism used, more studies are necessary to establish the ideal amount for the application in the culture of sugarcane, as smaller quantities of SCFC may not be sufficient to meet the demand of nutrients in certain types of soil.

\section{Acknowledgements}

We thank grant \#2012/02812-0, São Paulo Research Foundation (FAPESP).

\section{References}

ABNT - Associação Brasileira de Normas Tecnicas, 2004. NBR 10006: Procedimento para obtenção de extrato solubilizado de residuos solidos (Procedure for Obtention of Solubilized Extraction of Solid Wastes). ABNT, Rio de Janeiro.

ABNT - Associação Brasileira de Normas Técnicas, 2014. NBR 15537: Ecotoxicologia terrestre - Toxicidade aguda - Método de ensaio com minhocas (Lumbricidae) (Terrestrial ecotoxicology - Acute toxicity - Test method with earthworm (Lumbricidae)). ABNT, Rio de Janeiro.
APHA - American Public Health Association, 2012. Standard Methods for Examination of Water and Wastewater, twenty-second ${ }^{\text {nd }}$ ed. Water Environmental Federation, Washington.

Alvarenga, R.P., Queiroz, T.R., 2009. Produção mais Limpa e Aspectos Ambientais na Indústria Sucroalcooleira. In: $2^{\text {nd }}$ International Workshop Advances in Cleaner Productions, São Paulo, Brazil.

Bezerra, P.S.S., Takiyama, L.R., Bezerra, C.W.B., 2009. Complexacão de ions de metais por materia orgânica dissolvida: modelagem e aplicacão em sistemas reais. Acta Amaz. 39 (3), 639-649.

Bhat, S.A., Singh, J., Vig, A.P., 2014. Genotoxic assessment and optimization of pressmud with the help of exotic earthworm Eisenia fetida. Environ. Sci. Pollut. Res. 21, 8112-8123.

Bhat, S.A., Singh, J., Vig, A.P., 2016. Genotoxicity Reduction in Bagasse Waste of Sugar Industry by Earthworm Technology, vol. 5. SpringerPlus, p. 1186.

Bianchi, J., Fernandes, T.C.C., Marin-Morales, M.A., 2016. Induction of mitotic and chromosomal abnormalities on Allium cepa cells by pesticides imidacloprid and sulfentrazone and the mixture of them. Chemosphere 144, 475-483.

Bianchi, J., Espindola, E.L.G., Marin-Morales, M.A., 2011. Genotoxicity and mutagenicity of water samples from the Monjolinho River (Brazil) after receiving untreated effluent. Ecotoxicol. Environ. Saf. 74 (4), 826-833.

Bolboacă, S.D., Jäntschi, L., 2014. Sensitivity, specificity, and accuracy of predictive models on phenols toxicity. J. Comput. Sci. 5 (3), 345-350.

Budziak, C.R., Maia, C.M.B.F., Mangrich, A.S., 2004. Transformações químicas da matéria orgânica durante a compostagem de resíduos da indústria madeireira. Quím. Nova 27 (3), 339-403.

Bugg, T.D.H., Ahmad, M., Hardiman, E.M., Singh, R., 2011. The emerging role for bacteria in lignin degradation and bio-product formation. Curr. Opin. Biotechnol. 22, 394-400.

Bushra Ateeq, M., Abul Farah, M., Niamat ALI, W.A., 2002. Clastogenicity of pentachlorophenol, 2, 4-D and butachlor evaluated by Allium root tip test. Mutat. Res. 514, 105-113.

CETESB. Decisão de Diretoria no 195-2005-E, de 23 de novembro de, 2005. Dispõe sobre a aprovacão dos Valores Orientadores para Solos e Aguas Subterrâneas no Estado de São Paulo - 2005, em substituicão aos Valores Orientadores de 2001, e da outras providências. Diario Oficial do Estado de São Paulo, Poder Executivo, São Paulo, 3 dez. 2005. Secão 1, v. 115, n. 227, p.22-23. Retificacão no DOE, 13 dez. 2005, v. 115, n. 233, p. 42.

Christofoletti, C.A., Pedro-Escher, J., Correia, J.E., Marinho, J.F.U., Fontanetti, C.S., 2013. Sugarcane vinasse: environmental implications of its use. Waste Manag. 33 (12), 2752-2761.

CONAB - Companhia Nacional de Abastecimento, 2015. Acompanhamento da Safra Brasileira - Cana-de-açúcar. v. 2-Safra 2015/16, n. 3-Terceiro Levantamento, Brasília, pp. 1-65. Disponível em. http://www.conab.gov.br. ISSN 2318-7921.

Conceição, D.M., Angelis, D.A., Bidoia, E.D., Angelis, D.F., 2005. Fungos filamentosos isolados do rio Atibaia/SP e refinaria de petróleo biodegradadores de compostos fenólicos. Arq. Inst. Biol. 72 (1), 99-106.

Costa, E.C., Barbosa, C.D.E.S., Garcia, C.A.B., 2010. Estudos do processo de adsorção de metais pesados utilizando o pó do bagaço da Cana-de-açúcar para viabilização do seu uso em efluentes industriais. In: $62^{a}$ Reunião Anual da SBPC, Natal.

Donagema, G.K., de Campos, B.V.B., Calderano, S.B., Teixeira, W.G., Viana, J.H.M. 2011. Manual de metodos de analise de solos. Embrapa Solos, Rio de Janeiro, p. 230.

Dovgaliuk, A.I., Kaliniak, T.B., Blium, I.B., 2001. Cytogenetic effects of toxic metal salts on apical meristem cells of Allium cepa L. seed roots. TSitologiia i Genetika 35 (2), 3-10.

EPA - United States Environmental Protection Agency, 2007. Method 6010C (SW846): inductively coupled plasma-atomic emission spectrometry. Revision 3.

EPA - United States Environmental Protection Agency, 2004. Method 9040C (SW846): pH electrometric measurement. Revision 3.

Evseeva, T.I., Gera'kin, S.A., Shuktomova, I.I., 2003. Genotoxicity and toxicity assay of water sampled from a radium production industry storage cell territory by means of Allium- test. J. Environ. Radioact. Oxf. 68, 235-248.

Fernandes, T.C.C., Mazzeo, D.E.C., Marin-Morales, M.A., 2007. Mechanism of micronuclei formation in polyploidizated cells of Allium cepa exposed to trifluralin herbicide. Pesticide Biochem. Physiol. 88, 252-259.

Fernandes, T.C.C., Mazzeo, D.E.C., Marin-Morales, M.A., 2009. Origin of nuclear and chromosomal alterations derived from the action of an aneugenic agentTrifluralin herbicide. Ecotoxicol. Environ. Saf. 72 (6), 1680-1686.

Fiskesjö, G., 1988. The Allium test - an alternative in environmental studies: the relative toxicity of metal ions. Mutat. Res. Fundam. Mol. Mech. Mutagen. 197 (2), $243-260$.

Fusconi, A., Gallo, C., Camusso, W., 2007. Effects of cadmium on root apical meristems of Pisum sativum L.: cell viability, cell proliferation and microtubule pattern as suitable markers for assessment of stress pollution. Mutat. Res. Genetic Toxicol, Environ. Mutagen. 632 (1), 9-19.

Grant, W.F., 1994. The present status of higher plant bioassay for the detection of environmental mutagens. Mutat. Res. 310, 175-185.

Gupta, N., Tripathi, S., Balomajumder, C., 2011. Characterization of pressmud: a sugar industry waste. Fuel 90 (1), 389-394.

Herrero, O., Pérez Martín, J.M., Fernández Freire, P., Carvajal López, L., Peropadre, A., Hazen, M.J., 2012. Toxicological evaluation of three contaminants of emerging concern by use of the Allium cepa test. Mutat. Res. 743, 20-24.

Kumari, M., Khan, S.S., Pakrashi, S., Mukherjee, A., Chandrasekaran, N., 2011. Cytogenetic and genotoxic effects of zinc oxide nanoparticles on root cells of Allium 
cepa. J. Hazard. Mater. 190 (1), 613-621.

Kurás, M., Nowakowska, J., Sliwinska, E., Pilarski, R. Ilasz, R., Tykarska, T. Gulewicz, K., 2006. Changes in chromosome structure, mitotic activity and nuclear DNA content from cells of Allium Test induced by barck water extract of Uncaria tomentosa (Willd) DC. Chemosphere 107, 211-221.

Leite, A.F., Janke, L., Harms, H., Zang, J.W., Fonseca-Zang, W.A., Stinner, W. Nikolausz, M., 2015. Assessment of the variations in characteristics and methane potential of major waste products from the Brazilian bioethanol industry along an operating season. Energy Fuels 29, 4022-4029. http:// dx.doi.org/10.1021/ef502807s.

Leme, D.M., Marin-Morales, M.A., 2009. Allium cepa test in environmental monitoring: a review on its application. Mutat. Res. Rev. Mutat. Res. 682, 71-81.

Majer, B.J., Tscherko, D., Paschke, A., Wennrich, R., Kundi, M., Kandeler, E., Knasmüller, S., 2002. Effects of heavy metal contamination of soils on micronucleus induction in Tradescantia and on microbial enzyme activities: a comparative investigation. Mutat. Res. Genetic Toxicol. Environ. Mutagen. 515 (1), 111-124.

Matsumoto, S.T., Mantovani, M.S., Malagutti, M.I.A., Dias, A.L., Fonseca, I.C., MarinMorales, M.A., 2006. Genotoxicity and mutagenicity of water contaminated with tannery effluents, as evaluated by the micronucleus test and comet assay using the fish Oreochromis niloticus and chromosome aberrations in onion roottips. Genet. Mol. Biol. 29, 148-158.

Mazzeo, D.E.C., Fernandes, T.C.C., Levy, C.E., Fontanetti, C.S., Marin-Morales, M.A. 2015. Monitoring the natural attenuation of a sewage sludge toxicity using the Allium cepa test. Ecol. Indic. 56, 60-69.

Mazzeo, D.E.C., Fernandes, T.C.C., Marin-Morales, M.A., 2011. Cellular damages in the Allium cepa test system, caused by BTEX mixture prior and after biodegradation process. Chemosphere 85, 13-18.

Migid, A.H.M., Azab, Y.A., Ibrahim, W.M., 2007. Use of plant genotoxicity bioassay for the evaluation of efficiency of algal biofilters in bioremediation of toxic industrial effluent. Ecotoxicol. Environ. Saf. 66, 57-64.

MMA (Ministerio do Meio Ambiente). CONAMA-Conselho Nacional do Meio Ambiente. Resolucão No. 420/2009.

Montagnolli, R.N., Lopes, P.R.M., Bidóia, E.D., 2009. Applied models to biodegradation kinetics of lubricant and vegetable oils in wastewater. Int. Biodeterior. Biodegrad. 63 (3), 297-305.

Neves, M.F., Trombin, V.G., 2014. A dimensão do setor Sucroenergético: mapeamento e quantificação da safra 2013/14, Ribeirão Preto: Markestrat, Fundace, FEA-RP/USP.

Partha, N., Sivasubramanian, V., 2006. Recovery of chemicals from pressmud - a sugar industry waste. J. Indian Chem. Eng. 48 (3), 160-163.

Prado, Renato de Mello, Caione, Gustavo, Campos, Cid Naudi Silva, 2013. Filter cake and vinasse as fertilizers contributing to conservation agriculture. Appl. Environ. Soil Sci. 2013, 8. http://dx.doi.org/10.1155/2013/581984. Article ID 581984.

Rank, J., Nielsen, M.H., 1998. Genotoxicity testing of wastewater sludge using the Allium cepa anaphasetelophase chromosome aberration assay. Mutat. Res. 418, 113-119.

Rank, J., Lopez, L.C., Nielsen, M.H., Moretton, J., 2002. Genotoxicity of maleic hydrazide, acridine and DEHP in Allium cepa root cells performed by two different laboratories. Hereditas 136, 13-18.

Raut, D.N., Patil, T.B., Chaudhari, S.R., Pal, S.C., Mandal, S.C., 2014. Antimitotic effect of ethanol fractions of Hibiscus mutabilis leaf and flowers. Res. Pharm. 4 (5), $16-18$.
Sánchez, C., 2009. Lignocellulosic residues: biodegradation and bioconversion by fungi. Biotechnol. Adv. 27, 185-194.

Santos, V.C.G., Ferrarezi, J.G., Dragunski, D.C., 2008. Modificação química do bagaço de cana-de-açúcar para adsorção de chumbo e cromo. In: $31^{\mathrm{a}}$ Reunião Anual da Sociedade Brasileira de Química, São Paulo, Brazil.

Schimitz, J.A.K., Souza, P.V.D., Kämpf, A.N., 2002. Physical and chemical properties of substrats with mineral and organic origin for growth of potted plants. Ciência Rural. 32 (6), 937-944.

Seth, C.S., Misra, V., Chauhan, L.K.S., Singh, R.R., 2008. Genotoxicity of cadmium on root meristem cells of Allium cepa: cytogenetic and Comet assay approach. Ecotoxicol. Environ. Saf. 71 (3), 711-716.

Siedlecka, A., 1995. Some aspects of interactions between heavy metals and plant mineral nutrientes. Acta Soc. Bot. Pol. 64 (3), 265-272.

Steinkellner, H., Mun-Sik, K., Helma, C., Ecker, S., Ma, T.-H., Horak, O., Kundi, M., Knasmüller, S., 1998. Genotoxic effects of heavy metals: comparative investigation with plant bioassays. Environ. Mol. Mutagen. 31 (2), 183-191.

Souza, P.M.S., Corroqué, N.A., Morales, A.R., Marin-Morales, M.A., Mei, L.H.I., 2013a. Pla and organoclays nanocomposites: degradation process and evaluation of ecotoxicity using Allium cepa as test organism. J. Polym. Environ. 21, 1052-1063.

Souza, T.S., Heincklein, F.A., Angelis, D.F. Fontanetti, C.S., 2013b. Clastogenicity o landfarming soil treated with sugar cane vinasse. Environ. Monit. Assess. 185 1627-1636.

Souza, R.S., Moraes Santos, D.V., Morais Silva, V.L.M., 2009. Estudo da cinética de adsorção do bagaço da cana-de-açúcar na remoção de chumbo $(\mathrm{Pb})$. In: $2^{\circ}$ Congresso Químico do Brasil. Associação Norte-Nordeste de Química, Brazil.

Saplakoğlu, U., Iscan, M., 1998. Sister chromatid exchanges in human lymphocytes treated in vitro with cadmium in G0 and S phase of their cell cycles. Mutat. Res. 412, 109-114.

Trejo-Hernández, M.R., Ortiz, A., Okoh, A.I., Morales, D., Quintero, R., 2007. Biodegradation of heavy crude oil Maya using spent compost and sugar cane bagasse wastes. Chemosphere 68 (5), 848-855.

Ünyayar, S., Celik, A., Cekiç, F.O., Gözel, A., 2006. Cadmium-induced genotoxicity, cytotoxicity and lipid peroxidation in Allium sativum and Vicia faba. Mutagenesis 21 (1), 77-81.

Vitorino, L.B., Silva, A.A., Lana, R.M.Q., 2012. Influence of the fertilization with organic dejections and mineral fertilizer on the tenor of heavy metals in soil and sugarcane. Biosci. J. 28 (1), 72-82.

Weng, L., Temminghoff, E.J.M., Lofts, S., Tipping, E., Van Riemdijk, W.H., 2002 Complexation with dissolved organic matter and solubility control of heavy metals in a sandy soil. Environ. Sci. Technol. 36 (22), 4804-4810.

Wierzbicka, M., Antosiewicz, D. 1993. How lead can easily enter the food chain study of plant roots. Sci. Total Environ. 134, 423-429.

Wierzbicka, M., 1994. Resumption of mitotic activity in Allium cepa L. root tips during treatment with lead salts. Environ. Exp. Bot. 34 (2), 173-180.

Wierzbicka, M., 1999. Comparison of lead tolerance in Allium cepa with other plant species. Environ. Pollut. 104 (1), 41-52.

Yi, H., Wu, L., Jiang, L., 2007. Genotoxicity of arsenic evaluated by Allium-root micronucleus assay. Sci. Total Environ. 383, 232-236.

Yildiz, M., Ciğerci, I.H., Konuk, M., Fatih Fidan, A., Terzi, H., 2009. Determination of genotoxic effects of copper sulphate and cobalt chloride in Allium cepa root cells by chromosome aberration and comet assays. Chemosphere 75, 934-938.

Zhang, L., Sun, X., 2016. Improving green waste composting by addition of sugarcane bagasse and exhausted grape marc. Bioresour. Technol. 218, 335-343. 